\title{
Responsible Science: Celebrating the 50-year Legacy of Ball and Brown (1968) using a Registration-based Framework
}

Hiroyuki Aman; Wendy Beekes; Henk Berkman; Marc Bohmann; Mike Bradbury; Ellie Chapple; Millicent Chang; Victoria Clout; Robert Faff; Jianlei Han; David Hillier; Allan Hodgson; Bryan Howeison; Jonathan Jona; Martina Linnenluecke; Tiago Loncan; Browyn McCredie; David Michayluk; Nick Mroczkowski; Zheyao (Terry) Pan; Vinay Patel; Edward Podolski; Noami Soderstrom; Tom Smith; George Tanewski; Kathleen Walsh; Marvin Wee; Sue Wright

\begin{abstract}
This paper represents the intersection of three spheres of influence, highly relevant to the global research community interested in a more reliable understanding of capital market phenomena. First, as a timely context, we celebrate the 50-year legacy of an iconic paper on event studies, Ball and Brown (1968). Second, we add our voice to the growing call for researchers to follow principles of "responsible science". Third, using the Ball and Brown paper as their inspiration, we report on an experiment in which several teams of researchers follow a registration-based editorial process, which illustrates one fruitful avenue on how more responsible research can be fostered in the future.
\end{abstract}




\section{Introduction}

Our study brings together three spheres of influence, highly relevant to the global research community interested in a more reliable understanding of capital market phenomena. First, we celebrate the 50-year legacy of an iconic paper on event studies, Ball and Brown (1968) [BB68]. BB68 is shown to have a seminal influence, far beyond the seemingly narrow question it originally posed all those years ago (namely, around whether accounting information is useful). Second, we add our voice to the growing call for researchers to follow principles of "responsible science". For example, there are concerns that researchers make "subtle" research design choices that see a mid-term shift in the goal posts (The Economist 2016). ${ }^{1}$ Third, using the Ball and Brown paper as their inspiration, we provide a collective overview on an "experiment" in which several teams of researchers follow a registered research design that illustrates one angle on how more responsible research might be fostered in the future. This group of papers all published in the Pacific-Basin Finance Journal (PBFJ), constitutes a virtual special issue of the $P B F J$, for which our paper is the lead article.

BB68's core research question is: are accounting income numbers useful? If so, useful to whom? And for what purpose? ${ }^{2}$ The authors were broadly motivated by "a priori" research which dominated the accounting literature in the mid-1960s. The two central "knowns" at the time were: (1) historical cost (existing) financial statement information is meaningless; (2)

\footnotetext{
${ }^{1}$ The article in The Economist (2016), "For my next Trick ..." reported on the prevalence of outcome switching in clinical trials. Evidence shows that researchers fail to report on outcomes specified in the documents describing what the trial would be doing and, instead, choose to report on new outcomes that were not specified in the documents. Also see the following for additional discussion: BMC Medicine meta study (Helfer et al. 2015); PLOS ONE meta study (Donnelly et al. 2015); and COMPare group website: http://compare-trials.org/results.

${ }^{2}$ Ball and Brown (1968) is ostensibly an "accounting" study, though at the time leading up to its publication in the Journal of Accounting Research, its "accounting" credibility was far from agreed. Indeed, it is now well known that the paper was first rejected by the then Editor of The Accounting Review essentially because it is not accounting research (Howieson, 2019).
} 
radical changes to financial statement information is needed. But these "knowns" were not based on any objective/"scientific" evidence - such evidence was the big unknown that the field was desperately needing in order to advance as a "science". BB68 find: (1) information content of accounting income numbers is considerable; (2) accounting income numbers per se do not deliver very timely information; (3) an anomalous post-earnings announcement drift (PEAD), lasting up to 2 months. ${ }^{3}$ As documented by Clinch, Lyon, and Pinnuck (2019); Fargher and Wee (2019) and Howieson (2019) in this virtual special issue of PBFJ, BB68 had a phenomenal impact on scholarly research - not only in accounting, but also in finance and capital market studies. ${ }^{4}$ With a half-century of history behind it, it is now very timely to have this PBFJ special issue help us reflect on and warmly celebrate this iconic study.

The second element of our focus is motivated by the growing view that research is in a state of crisis. For example, (cRRBM 2017) have released a position paper on responsible research in business and management, primarily motivated by a credibility crisis in science. ${ }^{5}$ As they clearly state, the crisis has two related parts: (a) a crisis of integrity - “... the credibility of the knowledge published in journals is in doubt" [p.9] and (b) a crisis of relevance - the "... widening gap between research and practice, with business research in many domains increasingly divorced from the real-world practices" [p. 3]. The former of these issues is of particular relevance to our study, mainly in relation to one emerging practice across the broader

\footnotetext{
${ }^{3}$ See Appendix A for a wide-ranging but succinct summary of the scholarly thrust of their paper (utilising Faff's $(2015,2018)$ "pitching research" framework).

${ }^{4}$ Indeed, early in 2019, Professors Ray Ball and Philip Brown were awarded the Wharton-Jacobs Levy Prize for Quantitative Financial Innovation, for their 1968 paper. Specifically, the award recognises the significant and sustained influence that BB68 has had on practice in the finance industry, including investment analysis, portfolio management and the provision of financial data services.

${ }^{5}$ There are 28 founding members of the Community for Responsible Research in Business and Management (cRRBM), spanning all of the major Business School disciplines. Notable amongst this group are three leading finance scholars: Franklin Allen, Ulrich Hommel and Maureen O’Hara.
} 
scholarly journal community induced by the integrity crisis, namely, to publish academic articles that have come through a registration-based editorial process.

Prior to any (serious) data collection or empirical analysis within a registered design setting, an "in-principle accept" (IPA) decision is granted to research proposals deemed to be of sufficient merit. If the authors execute the study in line with the approved design and do not invoke some unforeseen major issue/concern that would render the IPA void, then publication will follow. The attractive feature of this process is that the credibility and careful execution of the design is all that matters - the fact that the findings might turn out to be statistically insignificant is of no consequence. In theory, this approach helps us fight against a perceived "positive" bias of findings in published papers ${ }^{6}$ - and help researchers avoid the evil temptations of "p-hacking" and HARKing. ${ }^{7}$ Munafo et al. (2017) recommend the registration approach as part of their broad manifesto for reproducible science. ${ }^{8}$ Registration “... makes clear the distinction between data-independent confirmatory research that is important for testing hypotheses, and data-contingent exploratory research that is important for generating hypotheses" (Munafo, et al., 2017, p. 3; emphasis added).

A significant subset of the current $P B F J$ special issue papers have followed a customised form of registration-based editorial process, as described later. These papers, with

\footnotetext{
${ }^{6}$ Among other things, Nosek and Lakens (2014) argue ignoring replications and negative results is bad science.

${ }^{7}$ According to Munafo et al. (2017), there is a related "reproducibility" crisis, i.e., that well-known published papers defy meaningful replication. These authors also suggest two seemingly common practices that add to the threat to reproducible science: p-hacking - or "data dredging" and HARKing - Hypotheses After the Results are Known.

8 The registration-based approach is not new in accounting or finance journals. In accounting, the Journal of Accounting Research (JAR) themed its 2017 annual research conference around registered reports. For details, see https://bit.ly/2zRkmUW. In finance, in 2017 the Review of Financial Studies put out two calls for "proposals" - one on the topic of FinTech and the other on Climate Finance. For details, see https://bit.ly/2SL2jHd and https://bit.ly/2QpFBaz, respectively.
} 
their chosen topics inspired by BB68, are: Aman et al. (2019); Berkman, Jona, and Soderstrom (2019); Bohmann et al. (2019); Han et al. (2019); Howieson (2019); and Hillier and Loncan (2019). ${ }^{9}$ There are several additional papers focusing on the Ball and Brown legacy included in the special issue (Ball and Brown 2019; Clinch, Lyon, and Pinnuck 2019; Fargher and Wee 2019).

The remainder of this paper is structured as follows. Section 2 provides a brief summary of the papers belonging to the virtual Special Issue of $P B F J$ that focus on the broader Ball and Brown legacy. Section 3 outlines the process and key elements underlying the registrationbased editorial process, founding the PBFJ virtual special issue. Section 4 then provides a brief commentary across the group of special issue papers. Section 5 gives voice to the reflections from each of authorship teams and the reviewers - especially, with regard to the challenges they faced around following a registered design. The focus here is "what worked", "what didn't work" and thinking about how an improved registration-based format might be developed as a regular article type at PBFJ. Section 6 concludes.

\section{Summary of PBFJ Special Issue Papers that Focus on the BB68 legacy}

Ball and Brown were commissioned by the current Editor-in-Chief of $P B F J$ to replicate BB68 for this virtual special issue, and to investigate "how different the USA results will be with over 50 years of more recent data and with a larger and possibly wider set of listed firms" (p.411,

\footnotetext{
${ }^{9}$ From the 12 initially 'signed-up' teams, six teams for varying reasons, did not make it through to the end (at the time of writing). However, it is hoped that after completing an appropriate review process one or two of these might eventually be "tagged into" the BB68 virtual special issue.
} 
Ball and Brown 2019). In the replication, the authors extended the time period examined to include data from 1971 to 2017 , and to include 16 other countries besides the US. Ball and Brown (2019) show that the principal findings documented in their original paper consistently replicate across this broader setting. That is, the "change in annual accounting earnings... continues to encapsulate a large fraction of the information that investors trade into share prices over the year" (p. 411).

In a qualitative study, Howieson (2019) investigates the perception of the influence that BB68 has had on accounting research, education, standard setting, and practice. The author conducts an extensive literature review and 27 interviews with subjects drawn from academe, practice and standard setting from around the world. The main research question here is: "whether BB68 constructed a monstrous paradigm akin to that of Frankenstein's creature or was it a work possessing the beauty of Venus?" (p.3 Howieson, 2019). The study provides insights into the reasons for the popularity of BB68 and explores both the positive and negative impacts of the research methodology inspired by BB68. The paper concludes with discussion on the future relevance of BB68 and the importance of striving for research excellence.

Two other papers are included in the special issue to examine the broader influence of BB68 - Clinch et al (2019) and Fargher and Wee (2019). Clinch et al (2019) review the impact of BB68 on accounting and finance research in the Asia-Pacific region. The authors consider impact by examining the magnitude and the nature of the published literature directly linked to BB68. Their analysis indicates that the level of impact of BB68 shows no signs of decline. Fargher and Wee (2019) consider the influence of BB68 using citation and visualisation techniques. They argue that direct citations greatly underestimate the impact of seminal research, and that simply by moving to two degrees of separation increases the number of citations of BB68 by an order of magnitude, relative to the number of direct citations. By 
studying the networks of citation relations, the authors suggest that we are better able to study the synergies between ideas that are a significant factor in stimulating research progress.

\section{Overview of the BB68 Special Issue Review Process}

As mentioned above, the virtual special issue also features several papers that have used BB68 as their inspiration. These papers are authored by teams of researchers who have followed a registered research design process. The papers that come through the process are given an "inprinciple accept" (IPA) decision prior to any (serious) data collection or empirical analysis. The attractive feature of this process is that the credibility and careful execution of the design is the prime concern - the fact that the findings might turn out to be statistically insignificant does not matter (Nosek and Lakens 2014). ${ }^{10}$

The process leading to this special issue began in mid-March 2017, with an email from the Editor-in-Chief of PBFJ, targeting various senior researchers (including Philip Brown), ${ }^{11}$ canvassing the broad concept of the Ball and Brown (1968) special issue built on a registrationbased editorial process. Based on a unanimity of positive responses, a framework of paper development and review was designed to capture a period of approximately 20 months. Some additional considerations included:

1) The topic of each paper must fit within the broad theme - have a sufficient link/focus to the broad literature spawned by BB68.

\footnotetext{
${ }^{10}$ As Nosek and Lakens (2014, p. 137) argue that registered reports are only a partial solution to research that lacks credibility, such studies are still subject to Type I and Type II errors.

11 To make the current experiment more expedient, the Editor-in-Chief took the view that it was better to commission teams led by senior and experienced researchers, rather than make an open call for "proposals". An open call would be a feature of any ongoing extension of this process in PBFJ in the future.
} 
2) All pitch teams formally attest to the ex-ante nature of the project - while some very preliminary work may have taken place, it is largely a new piece that will be substantially developed during the designated time window.

3) All main authors agree to be a reviewer on another special issue paper. The reviewing role is not anonymous and potentially quite "ongoing".

4) The review process has a three-phase design: (a) original pitch; (b) registered study design; (c) full paper review. Each of the stages is elaborated briefly below.

\subsection{Phase I: Original Pitch and Review}

Following the initial email in mid-March 2017, twelve team leaders were given a short period of time to determine their team's membership. Once team members were decided, the team had to supply a broad topic to the Special Issue Guest Editor by early-mid April 2017 (primarily to avoid any significant overlap in planned research). As its major task, the first phase involved each team creating an initial 1,000 word (maximum) initial research pitch based on Faff's $(2015,2018)$ "Pitching Research" framework. Moreover, each team was asked to deliver a written version and to present an oral pitch to an audience at one of the following symposia:

(a) International Accounting and Finance Doctoral Symposium (IAFDS) held in Krakow, Poland (15, June 2017) - four teams pitched here;

(b) Finance Special Interest Group, at the Accounting and Finance Association of Australia and New Zealand (AFAANZ) conference, held in Adelaide (1, July 2017) - seven teams pitched here;

(c) SIRCA Pitching Research Symposium, held at University of Technology Sydney (21, July 2017) - one team pitched here. 
Each oral pitch was given 30 minutes, comprising a 15-minute pitch and up to 15 minutes of discussion/brainstorming. In the case of each oral pitch, the feedback supplemented written feedback from the designated reviewers. Each team was given time to revise their Stage I pitches accordingly, with a further review required to allow each pitch to be "locked in", as a pathway towards the registered proposal in Phase II. The teams were warned that registered pitches must be deemed substantive, meaningful and sufficiently specific that PBFJ reviewers can get a sense of "accountability" around the credibility of the likely research design and associated outputs. The aim was to have this Phase I process completed by end of August 2017, but several teams required a longer period to achieve this step. Appendix A exhibits the full set of locked in pitches from Phase I.

\subsection{Phase II: Registered Study Design and Review}

It was explained to all teams, that the purpose of the Phase II "study registration" process is to cohesively build on the Phase I registered pitch and (in-principle) to agree on a set of research protocols that, if adhered to, will result in publication regardless of the nature of the results (subject to professional write up). It builds on and articulates with the phase I ["registered pitch"] process. A sufficiently rigorous and well-planned design must be formulated such that the results will be reliable, credible and reproducible, whether or not the ultimate findings prove statistically significant. This does not mean that ideas and tests that are outside the protocols are precluded or unimportant. Rather, the registration process will distinguish between confirmatory (hypothesis) testing [Part A] research, and post-registration analysis deemed to be "exploratory" [Part B]. It is therefore important that the registered project is specific enough to capture as much as possible in "Part A" of the published paper. The 
registration document should present a specific plan of the research, under three broad headings:

1) Registered Pitch;

2) Hypotheses; and

3) Method and Plan.

To assist researchers and reviewers, we developed a set of guidelines in the form a checklist. These Stage II guidelines are reproduced in Appendix B. The goal was to have each Phase II registered design lock in by early 2018. However, several teams struggled with this timeframe. Additionally, the review process took longer for Phase II than anticipated. Accordingly, several teams did not have their Phase II completed until April (or later) 2018. The Phase II registered study designs are available in the companion Internet appendix.

\subsection{Phase III: Full Paper Review}

The final phase involved a full paper review. This incorporated another oral presentation, timed to coincide with the 2018 AFAANZ Conference in Auckland. Specifically, teams were asked to present an update of their projects at the Finance SIG, held on 30 June 2018. A total of seven teams delivered this second oral presentation. ${ }^{12}$ Specifically, each team was allocated a $45-$ minute slot, comprising presentation and feedback components. Feedback was taken on board to help fine tune the full paper write up.

12 Due to time zone differences, scheduling and geographic obstacles, the Hillier and Loncan (2019) team did not deliver a second oral presentation. 
Teams were asked to complete and submit their final full paper for review - ideally, by the end of July 2018. However, several teams required more time to polish their full papers, prior to Phase III submission. Reviewers were asked to focus on:

1) compliance/ accountability/ conclusions,

2) identifying departure from the registered Phase II proposal, and

3) checking that, in the context of issues raised in item 2, (a) clear justification and explanation be given in the final paper and (b) such unplanned analysis is clearly segregated into a later section of "exploratory" or "post hoc" analysis.

\section{Brief Overview of BB68 Special Issue Empirical Papers}

The following are summaries of the five empirical papers that have followed the registrationbased process and are featured in the virtual special issue.

\subsection{Aman, Beekes, Chang and Wee}

BB68 inspired Aman et al. (2019) to better understand the relation between information released by a firm's managers in the form of the forecasts of the next year's earnings and analysts' forecasts of the same. In the way that BB68 investigated whether accounting information was useful (value relevant) and timely to the market, this study examines whether management's earnings forecasts provide useful information to analysts in forming their own forecasts and vice-versa.

Aman et al. (2019) extend BB68 by taking credibility into consideration, as is common place in the management forecast and analyst forecast literature today. They consider the role credibility plays in the analyst response and earnings expectation relationship by posing the following question: is the relation between management and analyst forecasts affected by assessments of the credibility of the forecast provider? Specifically, they study whether a 
moderating role exists for credibility in the relationship. Management credibility is evaluated by their prior forecasting ability and the firm's underlying corporate governance structure. On the other hand, analyst credibility is assessed using their prior forecasting ability.

Using a Structural Equation Modelling approach, the authors find management's credibility moderates the relation between management's initial earnings forecast for the year and subsequent analyst consensus forecasts. Consistent with expectations, analyst credibility has a moderating effect on the relation between analysts' consensus initial forecasts and management forecast revisions.

\subsection{Berkman, Jona and Soderstrom}

The research idea in Berkman, Jona, and Soderstrom (2019) is based on a related paper, Berkman, Jona, and Soderstrom (2018), which introduces a novel measure of firm-specific climate risk. Berkman, Jona, and Soderstrom (2019) propose to examine the impact of government commitment to combating climate change on firm value in relation to a firm's climate risk exposure. They first identified major recent regulatory events around climate change that are not fully predicted, including the surprise election of Donald Trump to President of the US and the Paris Climate Change agreement. Reminiscent of BB68, who focus on firms with good news versus bad news, the authors predicted opposite changes in value for polluting firms (with a high score on climate risk exposure) relative to non-polluting firms (with a low score on climate risk exposure) in reaction to these regulatory changes. Results are consistent with their expectations. For example, they find that around the surprise election of Donald Trump, the market value of firms with high climate risk increases relative to the value of firms with low climate risk, and they find the exact opposite results around the Paris Climate Change agreement, which represents an increased commitment to combatting climate change. 
This research relates to literature linking accounting disclosure to stock prices, going back to BB68 and Beaver (1968), as well as more recent evidence on the value relevance of mandatory risk disclosures (Campbell et al. 2014). Importantly, this study contributes to the literature on climate change and provides evidence that their climate risk metric, constructed from mandatory climate risk disclosures, is a useful summary measure of firm-specific climate risk that helps explain variation in market valuations across firms (see also Berkman et al. 2018).

\subsection{Bohmann, Michayluk, Patel and Walsh}

The authors are inspired by Ball and Brown $(1968 ; 2014)$ to focus on accounting information in the form of earnings announcements and examine the relationship with liquidity using an event study setting. Liquidity is a complex concept that can be measured in many ways, including using extremely detailed trading data but this is in stark contrast to the quarterly or half-yearly earnings data. Furthermore, concerns have emerged regarding the growth in the size, computation burdens and cost of using detailed microstructure data, as well as the suggestion that low-frequency liquidity measures in microstructure, asset pricing and corporate finance research may be just as effective. As a result, the authors examine whether data granularity increases our understanding of financial markets, that is, can low-frequency liquidity measures proxy for high-frequency benchmarks when there is information asymmetry in the market, specifically around Australian earnings announcements.

Their findings support the use of easily determined end of day measure. They find that the Closing-Percent-Quoted-Spread is the best proxy for quoted spreads, effective spreads, price impact and realised spreads when examining percent-cost liquidity measures. This result is robust using different correlation methods; root-mean-squared-error analysis; during the full sample, event, benchmark, pre-announcement and post-announcement periods around earnings announcements; and subsampling on earnings surprises, stock size, and around macroeconomic 
and institutional changes in the Australian market. Due to variability across correlation methodologies and subsamples, the authors suggest taking caution when using cost-per-dollar liquidity measures to proxy for high-frequency lambda, in particular, when used in time-series analysis.

Consistent with the findings of Goyenko, Holden, and Trzcinka (2009) and Fong, Trzcinka, and Holden (2017), the authors document that low-frequency measures can proxy for their high-frequency counterparts. Their findings provide initial evidence that cost and computational savings are available to interested parties, for example, analysis of informed trading in markets where high-frequency data is unavailable.

\subsection{Han, Linnenluecke, Pan and Smith}

Han et al. (2019) note that there is an identification problem when announcements have unresolved uncertainty. In this situation the method in BB68 cannot be applied because the price on announcement contains an outcome probability parameter as well as outcome price parameters. To solve this problem, the authors apply the method used in Barraclough et al. (2013). This method, which can be applied to any announcements with unresolved uncertainty, uncovers both probability and outcome parameters, and enables the price change on announcement to be split into news effects and valuation effects.

In their study, Han et al. (2019) are able to separate the news effect from the value effect associated with the announcement of the Australian Carbon Pricing Scheme (the "carbon tax") made on 24 February 2011. Their findings show that the news effect associated with the announcement is $1.11 \%$ (A $\$ 254$ million dollars), indicating that the market was favourably disposed towards the news that the government was taking action on climate change. The value effect was minus $4.46 \%$ (minus A $\$ 1.12$ billion dollars), indicating that the scheme destroyed significant value for existing firms. The announcement of the Australian Carbon Pricing 
Scheme was more value-destructive for carbon-intensive firms (minus 6.97\%) than for the other firms (minus 3.67\%).

\subsection{Hillier and Loncan}

Hillier and Loncan (2019) examine the relationship between political uncertainty and asset prices. The paper asks if political connections and foreign capital exposure influence how political uncertainty affects stock returns. The authors run an event study, exploiting an exogenous shock to political uncertainty in Brazil. Their findings suggest that the effect of political uncertainty on stock returns is stronger for politically connected firms and firms with higher exposure to foreign capital.

The research design is informed by BB68. The academic literature on political uncertainty often employs electoral periods as a source of political uncertainty affecting markets and firms. However, an issue with this approach is that political uncertainty around elections can be confused with economic policy uncertainty, since political parties can differ considerably in economic philosophy, and differences in economic orientation can affect asset prices in diverse ways.

By exploiting an exogenous shock to political stability, the authors capture the risks of a sudden and unexpected political fallout, one which endangered the very continuity of Brazil's presidential mandate. This event, for its unexpected nature, introduced new information content in stock prices, allowing the authors to investigate whether political connections and foreign capital exposure were factors in the price falls. In light of this, an event study design inspired by the pioneering work by Ball and Brown (1968) proved ideal for their analysis.

\section{Team Reflections}

All teams signed up for the BB68 special issue were asked to reflect on the registration process and provide responses to the following three questions: (1) what worked? (2) what did not 
work? and (3) how to improve? Below we summarise the reflections and include quotes from the individual teams where the reflections are particularly insightful.

\subsection{What worked?}

Given the concerns raised in Nosek and Lakens (2014) and Munafò et al. (2017), the teams are in support of the purpose and the use of the registered report process to improve the integrity of research. Most teams found the registration-based editorial process to be an effective way to safeguard and improve the quality of their research. One team commented that the "guidelines were very specific and intriguingly unusual" as teams were asked to present their research design before conducting the analysis and reference to the results. ${ }^{13}$ Others felt registering their research design forced thoughtful discussions early on that might otherwise have occurred once they started working with the data. The following reflections from two of the teams speaks to the pertinent issue of publishing a non-result paper where the research question is important.

"In using the pitch template to define the research question and to discuss the contributions, the team was able to clearly identify the need to conduct the project. This was done without concerns about whether we will find any significant results and of not being able to publish a "non-result" paper."

"[I]t was refreshing to be involved in a project where the strength of the idea matters more than the actual result. This approach aligns with what we tell our students, but do not practice in our field of academic research: it is the quality of the questions that matters and not the actual results".

Some teams commented more specifically on the interactions involved in the process.

It was noted that the interactions at the two conference presentations with the other author teams concurrently working on related projects were productive, resulting in better research

\footnotetext{
${ }^{13}$ While the teams were encouraged to investigate the availability of the data (primarily for feasibility reasons), they were asked not to commence any (serious) analysis until after the research design has been registered. In a few cases, some very basic descriptive statistics are actioned with eye on project feasibility.
} 
outcomes. One team found the process gave them "multiple opportunities to receive feedback and revise the paper accordingly" and that this helped with fine-tuning the write-up of their literature review. This also prompted them to compare their findings with those found using alternative approaches.

Another team noted that they "obtained continuous feedback on [their] choice of theories, research questions, methodologies and contribution". And that this "timely feedback, which was hugely beneficial, is normally relegated towards the end of a project, i.e., when it is presented at a conference or reviewed by a journal". The interactions with the other research teams and the referee, who was not anonymous, and the editors resulted in the teams having a sense of shared responsibility for the quality of the research. Others noted the benefits from the support provided from colleagues sharing the journey.

\subsection{What did not work?}

Although the teams were generally approving of the registration-based process, several areas did not work smoothly and could potentially be improved. All teams struggled, to varying degrees, with the ("foreign") requirement to specify the research design upfront. At one extreme, this proved difficult for one of the teams that did not have a strong history of working together, resulting in the team withdrawing the project from the special issue.

"The requirement ... meant that the team was locked into using a research design that might not, in hindsight, be best suited to answer the research questions. In the traditional editorial process, researchers continue to refine their research design to suit the distributions of their data (Bloomfield, Rennekamp, and Steenhoven 2018) and also to take into consideration feedback provided during the workshopping of the paper. ...[H]ence, led to difficulties in how the team most appropriately present the analysis to achieve the goal of conforming to the desired principles of responsible science".

"By the time we committed to a particular research design, we were unsure about the structure, nature and the level of detail of the data we would encounter in future steps. In hindsight, it would have been better to allow for some degree of flexibility in how to execute the paper methodologically. We came across many good ideas as to how we 
could improve our identification strategy, but because the research design was already locked-in, we had limited room to adapt".

Indeed, the above quotes indicate a quite understandable general "psychological" obstacle or barrier - due to a strong "anchoring" of research mindsets on the traditional process of doing research and getting published. Notably, this effect (to some extent) flows through in the final written papers of all empirical teams - manifested in a difficulty in understanding, clarifying and executing the "dividing line" between the registered analysis and any "post hoc" analysis. The requirement to register the research design for qualitative studies can be challenging due to the interpretative and exploratory nature of this type of research. However, the registration based process can still be used if the authors are mindful in explaining the registered analysis and any deviations.

"A potentially more serious issue is that some interviewees took an expansive approach to their reflections on BB68 and explored broad implications by, for instance, commenting upon the current state of accounting research. Consequently, it was sometimes necessary for me to make judgements about where the relevance of these comments to BB68 ended... All of these factors of judgement might be exercised differently by another researcher. I made every effort to be as objective as I could be in these processes and sought to support the judgements I have made by the frequent use of direct quotations as evidence."

The teams were required to present their pitches and research findings at two conferences. During these presentations, teams received additional feedback from the audience and other teams in attendance. This created conflicts for some teams as feedback received at the presentations could be inconsistent with those provided by the reviewers who may or may not be present at the presentations.

"One point of contrast with the traditional research process was some of the feedback we received conflicted with the referee. In general, a paper would normally be workshopped first and then submitted through the review process so this conflict would not arise. However this was only a minor issue". 
"The structured process produced comments and feedback that proved difficult to reconcile; in particular we became perplexed as to the weight and priority to accord to various sources".

There were also concerns with the time-frame for the projects. This was a major concern for two of the teams that failed to complete their project. One team was unable to meet the substantial commitment to collect and organise the data within the time frame permitted. For the other, the tight time-frame was a significant hurdle as their "ambitious" project involved hand-collected data. A related concern is the suitability of the registered design process to risky projects that might involve data that is not yet accessible or made available.

"Touch points for the research projects were primarily during two conferences. While each conference was helpful in different ways, the conference schedule imposed time constraints on the research projects. Timing of individual research projects is hard to predict, but in the current model, all projects were bound by the same deadlines".

"The only barriers we encountered to the registered design process were circumstance and time. First, a change in circumstance during the project changed our team membership, .... Second, the final deadline imposed by the experiment could not be met due to the size and nature of the hand-collected data to be collated and analysed. Consequently, this project is ongoing. In hindsight, our project was too exploratory for a registered design process, and we were too ambitious in our plans to hand collect and evaluate data..."

"After reviewing the aggregated data, which was adequate for macro-level but not micro-level data analysis, we knew we would be unable to achieve the primary objectives of our proposed research project and hence it was necessary for the research team to withdraw the proposal from the registered design process."

\subsection{How to improve?}

There are a number of suggestions offered by the teams to improve on the process. These suggestions include: improving the reviewing process; varying the timeframes for projects that might be viewed as more ambitious; adjusting the timing of when feedback was provided and allowing some more flexibility. 
First, there is a very different style of reviewing demanded by the nature of these manuscripts which is challenging, not only for the authors but also for the reviewers. The required style of reviewing needs a mindset that is very unfamiliar and, thus, disconcerting most notably, that neither statistical nor economic significance, per se, are of any relevance to the process. Hence, the review process could be improved by developing a detailed set of clear instructions, and possibly augmented by some training, on the art of reviewing pre-registered studies.

Second, on the issue of timeframes:

"[a] remedy... would be to have a yearly special issue and yearly conferences where, depending on the stage of the projects and how they have progressed, different projects would be showcased".

"The team would have benefited from more feedback at the earlier stages of the process. One way of achieving this is to better synchronise the second round of presentations with the Phase II proposal. The reviewer should be required to sign off on the proposal after the authors have incorporated comments and suggestions made during the last presentation".

"Redefine Phase 1 as 'research question or hypothesis development', and Phase II as 'model development and data collection', to ensure the feasibility of projects that might involve new models, and/or the collection or creation of original data".

Third, there are suggestions on providing more opportunities for the teams to receive feedback.

"In contrast to the standard process, where typically a paper is written and developed over many years and via workshops/presentations, the development of the registered paper relies on the comments of one referee. Relatively speaking, we feel that research papers are more likely to benefit from the wisdom of the crowd. Perhaps the sponsoring journal could provide more opportunities for presentation and/or opportunities to receive comments/feedback on the registered papers. We note that our referee provided comments which significantly improved the paper".

"[I]t would be helpful if the editors could stimulate inter-team communication outside of the conferences to gain further synergies across projects".

Finally, others argue for more flexibility in the process and allowing teams to modify the registered research design. 
"Perhaps the whole process could benefit from allowing more flexibility to adapt some aspects of the research design along the way. While the research questions, motivation and contributions of the original Pitch should remain unchanged throughout the project, at times new important relationships may emerge from the modelling exercise, or from the initial interpretation of results. Giving authors more space to adapt, without compromising the core aspects of responsible science, might be a way to improve the registered design process leading to the final version of the paper. This would also benefit the reviewers, as the more they are acquainted with the paper, the better are the suggestions for improvements".

While the above quote is a possible way forward, it also drives home a fundamental misconception: ${ }^{14}$ As Nosek and Lakens $(2014$, p. 138) argue, registered reports “... do not prevent or discourage exploratory analysis" and it "... does not mean that exploratory analysis is not valuable: it is just more tentative". Hence, it is imperative to give more careful guidance to prospective teams, emphasising that the underlying philosophy of the registered-design does indeed allow flexibility. Nevertheless, the heavy onus is on research teams getting the frontend design as good as and as detailed as it can be before any serious analysis takes place. Moreover, the dividing line between the registered analysis and any "post hoc" analysis is both important and empowering, once the researchers truly embrace the concept of "responsible science".

\footnotetext{
${ }^{14}$ A good example of the misconception is the following quote: "If this paper had been undertaken without the registered pitch there is a possibility we would have revised the sample or method".
} 


\section{Conclusions}

This virtual special issue of the $P B F J$ brings together a group of papers to celebrate the 50 -year legacy of Ball and Brown (1968) (BB68). As documented by Clinch, Lyon, and Pinnuck (2019); Fargher and Wee (2019) and Howieson (2019), BB68 has had an extraordinary impact on scholarly research - not only in accounting, but also in finance and capital market studies. Howieson (2019) noted that Ball and Brown's "preoccupation with research excellence" is perhaps the greatest contribution of BB68. It is widely acknowledged that the research conducted in BB68 required significant depth of thought and was conducted with considerable care. A testament of the quality of their research is the replicability of the results. Ball and Brown (2019) show that, 50 years later, the principal findings documented in their original paper consistently replicate across a broader setting, using more recent data and including 16 other countries in the sample.

Besides celebrating the legacy of BB68, this virtual special issue also provides us with the opportunity to add our voice to the call for "responsible science". In this lead article, we report on an experiment where several teams of researchers take up the challenge of conducting their research following a registration-based editorial process. Using the Ball and Brown paper as their inspiration, the researchers develop their research proposals and registered their research design prior to any data collection or empirical analysis. Accordingly, the teams were asked to clearly delineate the analysis conducted following their registered proposal versus any "post hoc" analysis. Overall, the teams involved are in support of the purpose and the use of the registered report process to improve the integrity of research. Nevertheless, several areas of the experiment did not work smoothly and are open to improvement. All teams struggled, to varying degrees, with the requirement to specify the research design upfront. Many team also had difficulties in drawing the "dividing line" between registered and "post hoc" analysis. 
Despite the challenges with the registration-based editorial process, the many identified positives suggest there is a need to continue experimenting with the registration-based editorial process; hopefully, better informed by the experience gained from our attempt, as documented herein. 


\section{References}

Aman, H., W. Beekes, M. Chang, and M. Wee, 2019, The role of credibility in the relation between management forecasts and analyst forecasts in Japan, Pacific-Basin Finance Journal 55, 29-45. Available from http://www.sciencedirect.com/science/article/pii/S0927538X18304918.

Ball, R., and P. Brown, 1968, An Empirical Evaluation of Accounting Income Numbers, Journal of Accounting Research 6, 159-178. Available from http://www.jstor.org/stable/2490232. , 2019, Ball and Brown (1968) after fifty years, Pacific-Basin Finance Journal 53, 410431. Available from http://www.sciencedirect.com/science/article/pii/S0927538X18306395.

Ball, R., and P. R. Brown, 2014, Ball and Brown (1968): A Retrospective, The Accounting Review 89, 1-26. Available from https://aaapubs.org/doi/abs/10.2308/accr-50604.

Barraclough, K., D. T. Robinson, T. Smith, and R. E. Whaley, 2013, Using option prices to infer overpayments and synergies in M\&A transactions, The Review of Financial Studies 26, 695-722.

Beaver, W. H., 1968, The information content of annual earnings announcements, Journal of Accounting Research, 67-92.

Berkman, H., J. Jona, and N. Soderstrom, 2019, Firm value and government commitment to combating climate change, Pacific-Basin Finance Journal 53, 297-307. Available from http://www.sciencedirect.com/science/article/pii/S0927538X18304578.

Berkman, H., J. Jona, and N. S. Soderstrom, 2018, Do Market Valuations Incorporate Climate Risk?, Working paper.

Bloomfield, R., K. Rennekamp, and B. Steenhoven, 2018, No System Is Perfect: Understanding How Registration-Based Editorial Processes Affect Reproducibility and Investment in Research Quality, Journal of Accounting Research 56, 313-362. Available from https://onlinelibrary.wiley.com/doi/abs/10.1111/1475-679X.12208.

Bohmann, M., D. Michayluk, V. Patel, and K. Walsh, 2019, Liquidity and earnings in event studies: Does data granularity matter?, Pacific-Basin Finance Journal 54, 118-131. Available

from http://www.sciencedirect.com/science/article/pii/S0927538X18304633.

Campbell, J. L., H. Chen, D. S. Dhaliwal, H.-m. Lu, and L. B. Steele, 2014, The information content of mandatory risk factor disclosures in corporate filings, Review of Accounting Studies 19, 396-455. Available from https://doi.org/10.1007/s11142-013-9258-3.

Clinch, G., J. D. Lyon, and M. Pinnuck, 2019, A review of the impact of Ball and Brown (1968) on research in the Asia-Pacific Basin, Pacific-Basin Finance Journal 53, 268-277. Available

from http://www.sciencedirect.com/science/article/pii/S0927538X18304670.

cRRBM, 2017, A Vision of Responsible Research in Business and Management: Striving for Useful and Credible Knowledge. Available from https://rrbm.network/wpcontent/uploads/2017/11/Position_Paper.pdf.

Donnelly, N.-A., A. Hickey, A. Burns, P. Murphy, and F. Doyle, 2015, Systematic Review and Meta-Analysis of the Impact of Carer Stress on Subsequent Institutionalisation of 
Community-Dwelling Older People, PLOS ONE 10, e0128213. Available from https://doi.org/10.1371/journal.pone.0128213.

Faff, R. W., 2015, A simple template for pitching research, Accounting \& Finance 55, 311336. Available from https://onlinelibrary.wiley.com/doi/abs/10.1111/acfi.12116.

, 2018, Pitching Research ${ }^{\circledR}$, Working paper. Available from Available at SSRN: https://ssrn.com/abstract=2462059 or http://dx.doi.org/10.2139/ssrn.2462059.

Fargher, N., and M. Wee, 2019, The impact of Ball and Brown (1968) on generations of research, Pacific-Basin Finance Journal 54, 55-72. Available from http://www.sciencedirect.com/science/article/pii/S0927538X18306164.

Fong, K. Y. L., C. A. Trzcinka, and C. W. Holden, 2017, What Are the Best Liquidity Proxies for Global Research?*, Review of Finance 21, 1355-1401. Available from https://doi.org/10.1093/rof/rfx003.

Goyenko, R. Y., C. W. Holden, and C. A. Trzcinka, 2009, Do liquidity measures measure liquidity?, Journal of Financial Economics 92, 153-181. Available from http://www.sciencedirect.com/science/article/pii/S0304405X09000099.

Han, J., M. K. Linnenluecke, Z. Pan, and T. Smith, 2019, The wealth effects of the announcement of the Australian carbon pricing scheme, Pacific-Basin Finance Journal 53, 399-409. Available from http://www.sciencedirect.com/science/article/pii/S0927538X1830386X.

Helfer, B., A. Prosser, M. T. Samara, J. R. Geddes, A. Cipriani, J. M. Davis, D. Mavridis, G. Salanti, and S. Leucht, 2015, Recent meta-analyses neglect previous systematic reviews and meta-analyses about the same topic: a systematic examination, BMC Medicine 13, 82. Available from https://doi.org/10.1186/s12916-015-0317-4.

Hillier, D., and T. Loncan, 2019, Political uncertainty and Stock returns: Evidence from the Brazilian Political Crisis, Pacific-Basin Finance Journal 54, 1-12. Available from http://www.sciencedirect.com/science/article/pii/S0927538X18303822.

Howieson, B., 2019, Frankenstein's Monster or the Birth of Venus? Perceptions of the Impact and Contributions of Ball and Brown 1968, Pacific-Basin Finance Journal Forthcoming.

Munafò, M. R., B. A. Nosek, D. V. M. Bishop, K. S. Button, C. D. Chambers, N. Percie du Sert, U. Simonsohn, E.-J. Wagenmakers, J. J. Ware, and J. P. A. Ioannidis, 2017, A manifesto for reproducible science, Nature Human Behaviour 1, 0021. Available from https://doi.org/10.1038/s41562-016-0021.

Nosek, B. A., and D. Lakens, 2014, Registered Reports, Social Psychology 45, 137-141. Available from https://econtent.hogrefe.com/doi/abs/10.1027/1864-9335/a000192.

The Economist, 2016, For my next trick... The Economist. 
Figure 1: Summary of Ball and Brown (1968) $)^{15}$

\begin{tabular}{|c|c|}
\hline (A) Full Reference ${ }^{16}$ & $\begin{array}{l}\text { Ball, R. and Brown, P., (1968), “An Empirical Evaluation of Accounting Income Numbers”, Journal of Accounting Research 6, 159- } \\
178 .\end{array}$ \\
\hline $\begin{array}{l}\text { (B) Basic } \text { Research } \\
\text { Question }\end{array}$ & Are accounting income numbers useful? If so: useful to whom? And for what purpose? \\
\hline (C) Key paper(s) & $\begin{array}{l}\text { Fama, E., Fisher, L., Jensen, M. and Roll, R., (1969), “The Adjustment of Stock Prices to New Information", International Economic } \\
\text { Review 10, 1-21. [FFJR] } \\
\text { Fisher, L., (1966), "Some New Stock Market Indices", Journal of Business 39, 191-225. } \\
\text { Miller, M. and Modigliani, F., (1966), "Some Estimates of the Cost of Capital to the Electric Utility Industry, 1954-57”, American } \\
\text { Economic Review 61,333-391. }\end{array}$ \\
\hline (D) Motivation/Puzzle & $\begin{array}{l}\text { "a priori" research dominated the accounting literature in the mid-1960s. The TWO central "knowns" at the time: (1) existing financial } \\
\text { statement information is meaningless; (2) radical changes to financial statement information is needed. But these "knowns" were not } \\
\text { based on any objective/"scientific" evidence - such evidence was the big unknown that the field was "crying out for" [though at an } \\
\text { individual researcher level, many were not "desperate" for this evidence]. }\end{array}$ \\
\hline THREE & Three core aspects of any empirical research project i.e. the "IDioTs" guide \\
\hline (E) Idea? & $\begin{array}{l}\text { The broad setting is the stock market and how it reacts to information. The efficient market hypothesis (EMH) is the foundational } \\
\text { base for the study - EMH implies that stock prices react very quickly to new firm-relevant information, and in an unbiased fashion. } \\
\text { BB68 focused on annual earnings news and pooled observations centred on firm announcements. The observable accounting income } \\
\text { numbers allow a reasonably direct test of whether the incumbent financial statement information is meaningless. The basic prediction } \\
\text { (hypothesis) is that the "newsworthy" part of accounting income numbers possess material information that is associated with investor } \\
\text { decisions, as manifested by observed stock price changes. The prediction was far less about "if" this (earnings news-stock price return) } \\
\text { association existed, BUT much more about the strength of the relation. }\end{array}$ \\
\hline (F) Data? & $\begin{array}{l}\text { (1) Annual earnings numbers covering } 1946-1966 \text { from Compustat. (2) Announcement dates from WSJ - taken as the date of } \\
\text { preliminary earnings report or of the complete report (where a preliminary is not announced). (3) Stock price relatives obtained from } \\
\text { CRSP (monthly, adjusted for dividends and capital changes) - natural log transformed to produce continuously compounded returns. } \\
\text { Firm inclusion criteria: complete earnings data; } 31 \text { December year end; minimum } 100 \text { months of price data; WSJ announcement dates } \\
\text { available. Sample effectively restricted to } 9 \text { years: } 1957-1965 \text {. Sample covers N }=287 \text { firms. Recognition of a survivorship bias. }\end{array}$ \\
\hline
\end{tabular}

15 This worked RE pitch has been heavily informed by Ball and Brown (2014).

${ }^{16}$ First version title: “A Theoretical and Empirical Evaluation of Accounting Income Numbers”. Second version title: "The Information Value of the Annual Earnings Report”. 


\begin{tabular}{|c|c|}
\hline (G) Tools? & $\begin{array}{l}\text { As has now become well-known and widely entrenched, BB } 68 \text { created an insightful first version of the "event study" design in } \\
\text { accounting. Exploiting the calendar time concept developed by FFJR, assessing the incremental reaction to the type of news being } \\
\text { released. This required identifying the "newsworthy" component of earnings announcements and that component of the stock price } \\
\text { change not attributable to general market movements. It was critical to have a tool that identified the timing of the information and } \\
\text { the type of news. The basic approach was to simply apply a binary partition into whether the income number was above (below) } \\
\text { expected, designated as "good" ("bad") news. }\end{array}$ \\
\hline TWO & Two key questions \\
\hline (H) What's New? & $\begin{array}{l}\text { (1) Research method: introduced the event study method into accounting - giving accounting research its first real taste of "scientific" } \\
\text { rigor. (2) Distinguished and disentangled the notions of "information content" versus "information timeliness", when asking the } \\
\text { question "are accounting income numbers useful?" }\end{array}$ \\
\hline (I) So What? & $\begin{array}{l}\text { Before the fact, the study would either confirm the received view (that accounting information) is useless or (as was found) find } \\
\text { evidence that such information is useful and thereby seriously challenge this prevailing view. }\end{array}$ \\
\hline ONE & One bottom line \\
\hline (J) Contribution? & $\begin{array}{l}\text { BB68 provides evidence that accounting matters because of its informational usefulness, despite its lack of timeliness. By challenging } \\
\text { the prevailing view that "accounting income information is useless", the underlying fundamental "paradigm" suggesting alternative } \\
\text { accounting schemes was put in "crisis mode" - akin to the concept of a "scientific revolution" (Kuhn 1969, UCP). Put differently, } \\
\text { while conducted in the spirit of positive economics, BB68 has distinct normative implications: by rejecting the prevailing view of } \\
\text { "what is", it raised a serious "red flag" over the status of linked claims of "what ought to be". As } 50 \text { years of history has borne out, } \\
\text { this contribution proved utterly seminal in nature, spawning a huge literature with many sub-parts that in several cases created } \\
\text { derivative seminal works in the 1970s and 1980s. }{ }^{17} \text { As such, the full contribution of BB68 can now be gauged by a "multi-generational" } \\
\text { evolution of related contemporary studies that all derive their pedigree back to the "grand-father" study of them all, BB68. BB68 } \\
\text { opened the door for deep research into how users employ accounting numbers - "investors, analysts, lenders, rating agencies, litigants, } \\
\text { and competitors, and its use in compensation, supply, and other contractual contexts" [Ball \& Brown, 2014, TAR]. }\end{array}$ \\
\hline (K) Three Key Findings & $\begin{array}{l}\text { (1) Information content of accounting income numbers is considerable. (2) Accounting income numbers per se do NOT deliver very } \\
\text { timely information. (3) Documented an anomalous post-earnings announcement drift (PEAD), lasting up to } 2 \text { months. }\end{array}$ \\
\hline
\end{tabular}

${ }^{17}$ See Fargher and Wee (2019). 
Appendix A: Stage I Registered Pitches for BB68 Special Issue ${ }^{a}$ Summary Original Pitch Teams

\begin{tabular}{|c|c|c|c|c|}
\hline & Pitch Team Leader & Affiliation & $\begin{array}{l}\text { Conference/ } \\
\text { Symposium }\end{array}$ & Working Title \\
\hline 1 & David Hillier and Tiago Loncan & U of Strathclyde & IAFDS & $\begin{array}{l}\text { Political Uncertainty, Stock Market Performance and Corporate } \\
\text { Behaviour }\end{array}$ \\
\hline 2 & $\begin{array}{l}\text { Marc Bohman, David Michayluk, } \\
\text { Vinay Patel, and Kathleen Walsh }\end{array}$ & U of Technology Sydney & IAFDS & $\begin{array}{l}\text { Liquidity and earnings in event studies: Does data granularity } \\
\text { matter? }\end{array}$ \\
\hline 3 & Bryan Howieson & U of Adelaide & AFAANZ & $\begin{array}{l}\text { Frankenstein's Monster or the Birth of Venus? Perceptions of the } \\
\text { Contribution of Ball and Brown } 1968\end{array}$ \\
\hline 4 & Ellie Chapple \& Victoria Clout & $\begin{array}{l}\text { Queensland U of } \\
\text { Technology, U of NSW }\end{array}$ & AFAANZ & $\begin{array}{l}\text { The High Road or the Low Road? The Information Environment } \\
\text { Around Backdoor Listing }\end{array}$ \\
\hline 5 & $\begin{array}{l}\text { Henk Berkman, Jonathan Jona, } \\
\text { Noami Sunderholm }\end{array}$ & $\begin{array}{l}\text { U of Auckland, } \\
\text { U of Melbourne }\end{array}$ & AFAANZ & $\begin{array}{l}\text { Government commitment to combatting climate change and firm } \\
\text { value }\end{array}$ \\
\hline 6 & $\begin{array}{l}\text { Jianlei Han, Martina Linnenluecke, } \\
\text { Zheyao (Terry) Pan and Tom Smith }\end{array}$ & Macquarie U & AFAANZ & Wealth Effects of Carbon Tax Policy in Australia \\
\hline 7 & $\begin{array}{l}\text { Hiroyuki Aman, Wendy Beekes, } \\
\text { Millicent Chang and Marvin Wee }\end{array}$ & $\begin{array}{l}\text { Kwansei Gakuin U, U of } \\
\text { Lancaster, U of } \\
\text { Wollongong, Australian } \\
\text { National U }\end{array}$ & AFAANZ & $\begin{array}{l}\text { The Properties of Management Forecasts and their Impact on } \\
\text { Analysts Forecasts in Japan }\end{array}$ \\
\hline 8 & Sue Wright and Bronwyn McCredie & $\begin{array}{l}\text { U of Technology Sydney, } \\
\text { Queensland U of } \\
\text { Technology }\end{array}$ & SIRCA & Fight or Flight: CEO human capital during financial distress \\
\hline 9 & $\begin{array}{l}\text { Allan Hodgson, Stacey Beaumont, } \\
\text { Raluca Ratiu and Zhengling Xiong }\end{array}$ & U of Queensland/IE & IAFDS & Are insiders aware of the winner/loser arbitrage? \\
\hline 10 & $\begin{array}{l}\text { Nick Mroczkowski, Edward } \\
\text { Podolski and George Tanewski }\end{array}$ & Deakin U & IAFDS & $\begin{array}{l}\text { Do Private Firms Engage in Tax Avoidance Activities? An Event } \\
\text { Study of Tax Advantage }\end{array}$ \\
\hline 11 & $\begin{array}{l}\text { Searat Ali, Muhammad Atif, } \\
\text { Sivathaasan Nadarajah }\end{array}$ & $\begin{array}{l}\text { U of Wollongong, Griffith } \\
\mathrm{U}\end{array}$ & AFAANZ & $\begin{array}{l}\text { Does Environment, Social and Governance disclosures affect } \\
\text { information asymmetry and insolvency risk? Global evidence }\end{array}$ \\
\hline
\end{tabular}

${ }^{a}$ While twelve teams initially signed up: three teams failed to deliver an approved Phase I pitch, with one of these electing to remain anonymous. 
A1: Phase I Registered Pitch - Political Uncertainty in Brazil

\begin{tabular}{|c|c|c|c|}
\hline Pitcher's Name & David Hillier \&Tiago Loncan & Date Completed & 22/08/2017 \\
\hline (D) Motivation/Puzzle & \multicolumn{3}{|c|}{$\begin{array}{l}\text { Political uncertainty can shake stock markets, with adverse effects spilling-over particularly in real economic variables, such as } \\
\text { investment cycles. However, how political turmoil affects firms at the cross-sectional level remains less clear. In principle, when } \\
\text { political uncertainty unfolds, politically connected firms and state-owned firms are most exposed, for their growth options and their } \\
\text { very ownership structures can be severely affected by the turmoil's outcome. While the impact of political uncertainty in emerging } \\
\text { market settings has had recent high profile attention (e.g. China focus of Liu, et al., 2017), the often magnified controversy and } \\
\text { lingering "bad" behaviour gives the ongoing opportunity for nuanced insights, which adds extra appeal for seeking further evidence } \\
\text { in such less-developed markets. }\end{array}$} \\
\hline & \multirow{2}{*}{\multicolumn{3}{|c|}{$\begin{array}{l}\text { Three core aspects of any empirical research project i.e. the "IDioTs" guide } \\
\text { In this paper, we study whether political uncertainty produces idiosyncratic effects on politically linked firms, in terms of valuation, } \\
\text { investment and financing structure. We study the Brazilian political crisis, which begun by the time of the presidential elections of } \\
2014 \text { and is still unfolding. Brazil is an ideal laboratory for a study of this nature for a number of reasons. First, the government } \\
\text { responded to the } 2008 \text { financial crisis by increasing subsidies to the private sector, with aggressive handouts via both equity and debt } \\
\text { to large and friendly firms, so-called "National Champions" provided by the state-owned bank BNDES. This policy created an } \\
\text { interesting treatment group of politically connected firms. For this policy, in a recent article The Financial Times referred to BNDES } \\
\text { as a "Lender of first resort to Brazilian tycoons". } \\
\text { Second, the country has been facing a period of strong political instability, rooted in the largest corruption probe in the country's } \\
\text { history, the "Carwash Task Force", which investigates corruption schemes in the state-owned oil company Petrobras. By the time } \\
\text { election race started, a number of high-profile politicians from the incumbent party (Partido dos Trabalhadores) were already jailed } \\
\text { on corruption charges (including former state ministers and the party's treasurer). Though the incumbent government had support } \\
\text { from the masses, strongly related to income transfer programmes, and from business tycoons, due to subsidy policies, the party was } \\
\text { in the spotlight for corruption and wrongdoing as well, what made the outcome of this election particularly uncertain. Clearly, those } \\
\text { firms with political capital had much to gain or lose in this race. }\end{array}$}} \\
\hline & & & \\
\hline
\end{tabular}




\begin{tabular}{|c|c|}
\hline & $\begin{array}{l}\text { Political instability was only partially resolved with the election result. Less than two years after the incumbent party secured office, } \\
\text { the president was impeached, adding another event of uncertainty to our story. Another major political event occurred in } 2017 \text {, right } \\
\text { after the vice-president replaced the former impeached president. The (new) president was tapped while condoning bribes to silence } \\
\text { a key witness in the Car Wash probe, putting in check his mandate. This event ignited an immediate adjustment in the Brazilian stock } \\
\text { market, which fell sharply by almost } 10 \% \text {. Recently, the government voted important political reforms (with the labour bill at the } \\
\text { epicentre), adding more and more complexity to the political scenario. } \\
\text { Given the above context, our goal is to run event studies around key political event dates, studying whether stock prices, investment } \\
\text { and financing choice decisions from politically connected firms are affected differently to innovations in informational content arising } \\
\text { from a resolve or escalation of political uncertainty. We propose the following (tentative) hypotheses. First, when political uncertainty } \\
\text { threatens incumbent governments, stock prices of politically connected firms undergo stronger devaluations, because the risk of } \\
\text { turnover in government reduces the market value of such political ties. Second, uncertainty marginally reduces the the future value of } \\
\text { growth opportunities, for future investments may be contingent upon government support, hitting harder on politically linked firms' } \\
\text { investment cycles. Third, akin to a bad business cycle, politically connected firms may turn to more conservative financial policies } \\
\text { (accumulating cash and/or deleveraging), to mitigate risk exposure. }\end{array}$ \\
\hline (F) Data? & $\begin{array}{l}\text { Data for publicly listed firms from Brazil, sourced from Osiris (Bureau Van Dijk). For stock prices we will work with daily data, } \\
\text { whilst for financial data we build on quarterly data from financial statements. To build our portfolio of politically connected firms, } \\
\text { we use data from BNDES, which tracks the banks' investments in equity and debentures (and corporate donations to the } 2014 \text { elections } \\
\text { as a potential second identification strategy). }\end{array}$ \\
\hline (G) Tools? & $\begin{array}{l}\text { In the stock price analysis, we run event studies around key dates, such as the first and second round of the presidential elections in } \\
2014 \text {, and the impeachment announcement and in } 2015 / 2016 \text {, around political reforms voting in congress. In the corporate behaviour } \\
\text { analysis, we use diff-in-diff (D-i-D) analysis. The idea is to study corporate behaviour (investment and financing choices as dependent } \\
\text { variables) around financial quarters in which important political events took place, with dummy variables identifying political } \\
\text { uncertainty cycles, in particular during presidential elections. The treated group includes politically connected firms, whilst other firms } \\
\text { are placed in the control group. Consistent with D-i-D methodology, the interaction term between treated firms and the dummy } \\
\text { capturing political uncertainty periods captures idiosyncratic corporate behaviour of politically connected firms during the period of } \\
\text { uncertainty. } \\
\text { With respect to methodological aspects, two potential problems inherent to event studies deserve comment. The first is Event Date } \\
\text { Uncertainty. The potential for event date misspecification arises whenever price data are reported more precisely than information } \\
\text { about the event date (Ball and Torous, 1988, JFE). This problem seems to be more relevant when studying corporate events, because } \\
\text { some agents may anticipate the outcome (asymmetric information), thus creating a wedge between the announcement of the event } \\
\text { and the impact on asset prices. As we study political events, which are announced at the same time for all investor community (like } \\
\text { an election outcome), it seems likely that the event announcement date indeed matches with the real event date. The second issue is } \\
\text { whether political events overlap with one another, as we study a whole period of continued political instability. We can run robustness } \\
\text { checks with shorter event windows to try and separate the effects of each political uncertainty shock. }\end{array}$ \\
\hline
\end{tabular}




\begin{tabular}{|l|l|}
\hline TWO & Two key questions \\
\hline (H) What's New? & $\begin{array}{l}\text { The originality of the work is to study the issue of political uncertainty, stock prices and corporate behaviour in a quasi-natural } \\
\text { experiment setting, with highly unpredictable outcomes akin to a particularly turbulent political cycle. Moreover, we also innovate by } \\
\text { bringing firm characteristics to the analysis, studying the role played by political connectedness in detail. }\end{array}$ \\
\hline (I) So What? & $\begin{array}{l}\text { Prior research has shown that political uncertainty creates undesirable effects both for finance and real economic variables, with higher } \\
\text { equity premiums demanded by investors, increased volatility and depressed investment. Our study sheds more light on the mechanisms } \\
\text { through which political uncertainty kicks in both for asset prices and investment. }\end{array}$ \\
\hline ONE & One bottom line \\
\hline (J) Contribution? & $\begin{array}{l}\text { We contribute to the political economy of finance debate, in particular by providing a firm-level examination of political uncertainty } \\
\text { and its outcomes. Our study has important implications for financial efficiency and capital allocation in an emerging market setting. }\end{array}$ \\
\hline (K) Other Considerations & $\begin{array}{l}\text { We acknowledge some risks involved in our research, in particular competition risk - other researchers might be exploring the same } \\
\text { identification strategy based on politically-connected firms, as the BNDES data are publicly available. }\end{array}$ \\
\hline
\end{tabular}


A2: Phase I Registered Pitch - Liquidity and Earnings

\begin{tabular}{|c|c|c|c|}
\hline Pitcher's Name & $\begin{array}{l}\text { Marc Bohman, David Michayluk, Vinay } \\
\text { Patel, and Kathleen Walsh }\end{array}$ & Date Completed & 21 May 2017 \\
\hline (A) Working Title & \multicolumn{3}{|c|}{ Liquidity and earnings in event studies: Does data granularity matter? } \\
\hline $\begin{array}{l}\text { (B) Basic Research } \\
\text { Question }\end{array}$ & \multicolumn{3}{|c|}{ What are the merits of low versus high frequency liquidity measures in the context of earnings announcement event studies? } \\
\hline (C) Key paper(s) & \multicolumn{3}{|c|}{$\begin{array}{l}\text { Fong, K. Y. L., C. W. Holden, and C. A. Trzcinka (2017). What Are The Best Liquidity Proxies For Global Research? Review of } \\
\text { Finance, 21, 4, , 1355-14016, This paper compares low frequency and high frequency liquidity measures. } \\
\text { Kim, O., \& Verrecchia, R. E. (1994). Market liquidity and volume around earnings announcements. Journal of Accounting and } \\
\text { Economics, 17, 41-67. This paper posits that there are significant information asymmetries around earnings announcements and this } \\
\text { is likely to be higher than in non-announcement periods. More information asymmetries imply higher liquidity costs and the Fong et } \\
\text { al paper didn't control for this issue. } \\
\text { Ball, R., and P. Brown. (1968). An empirical evaluation of accounting income numbers. Journal of Accounting Research } 6 \text { (2): 159- } \\
\text { 178. This paper provides the underlying event study methodology with linkages to financial accounting information that allows us to } \\
\text { test low frequency proxies for high frequency measures during periods of changing information asymmetry. }\end{array}$} \\
\hline (D) Motivation/Puzzle & \multicolumn{3}{|c|}{$\begin{array}{l}\text { Data has been increasingly granular and particularly in market microstructure, the availability of very detailed information, sometimes } \\
\text { multiple transaction per second recorded in micro or nano-seconds, makes estimation of liquidity variables incredibly precise. These } \\
\text { more precise measures come at a large computational cost yet for event studies that examine earnings announcements the increased } \\
\text { precision may, or may not, have an influence on the findings in these studies. Current literature is unclear on whether there is any gain } \\
\text { to using more precise measures and if computational savings are available for researchers across the multi-faceted nature of very rich } \\
\text { data, high dimensional data that is becoming more readily available. }\end{array}$} \\
\hline THREE & \multicolumn{3}{|c|}{ Three core aspects of any empirical research project i.e. the "IDioTs" guide } \\
\hline (E) Idea? & \multicolumn{3}{|c|}{$\begin{array}{l}\text { This paper will investigate the trade-off between the precision and computational cost of liquidity estimation using high frequency } \\
\text { data versus estimation using low frequency data. It is likely that the computational cost of high frequency data does not translate to } \\
\text { efficient estimation precision. However, it is expected that liquidity measured with low frequency data would be adequate under } \\
\text { normal market conditions but would be imprecise during periods of stress such as periods of information asymmetry. } \\
\text { Our research will determine whether there is any meaningful gain to using more precise measures and will determine if computational } \\
\text { savings are available for researchers with large samples, long sample periods, varying information asymmetries or across multiple } \\
\text { countries. We will apply a "cost-benefit" logic to our analysis which is essentially a "horse race" measuring the trade-offs between } \\
\text { computational cost and measurement precision under varying levels of information asymmetry. }\end{array}$} \\
\hline (F) Data? & \multicolumn{3}{|c|}{$\begin{array}{l}\text { We plan to use Australian data over } 2006-2017 \text { for } 222 \text { companies. We are examining earnings announcements in event studies and } \\
\text { this period has a sufficient length of time and cross-section of results. Data source is TRTH. It is likely that the correlation across }\end{array}$} \\
\hline
\end{tabular}




\begin{tabular}{|c|c|}
\hline & $\begin{array}{l}\text { liquidity measures is not uniform across size so the sample under investigation needs to include both large and small cap stocks in an } \\
\text { active financial market. }\end{array}$ \\
\hline (G) Tools? & 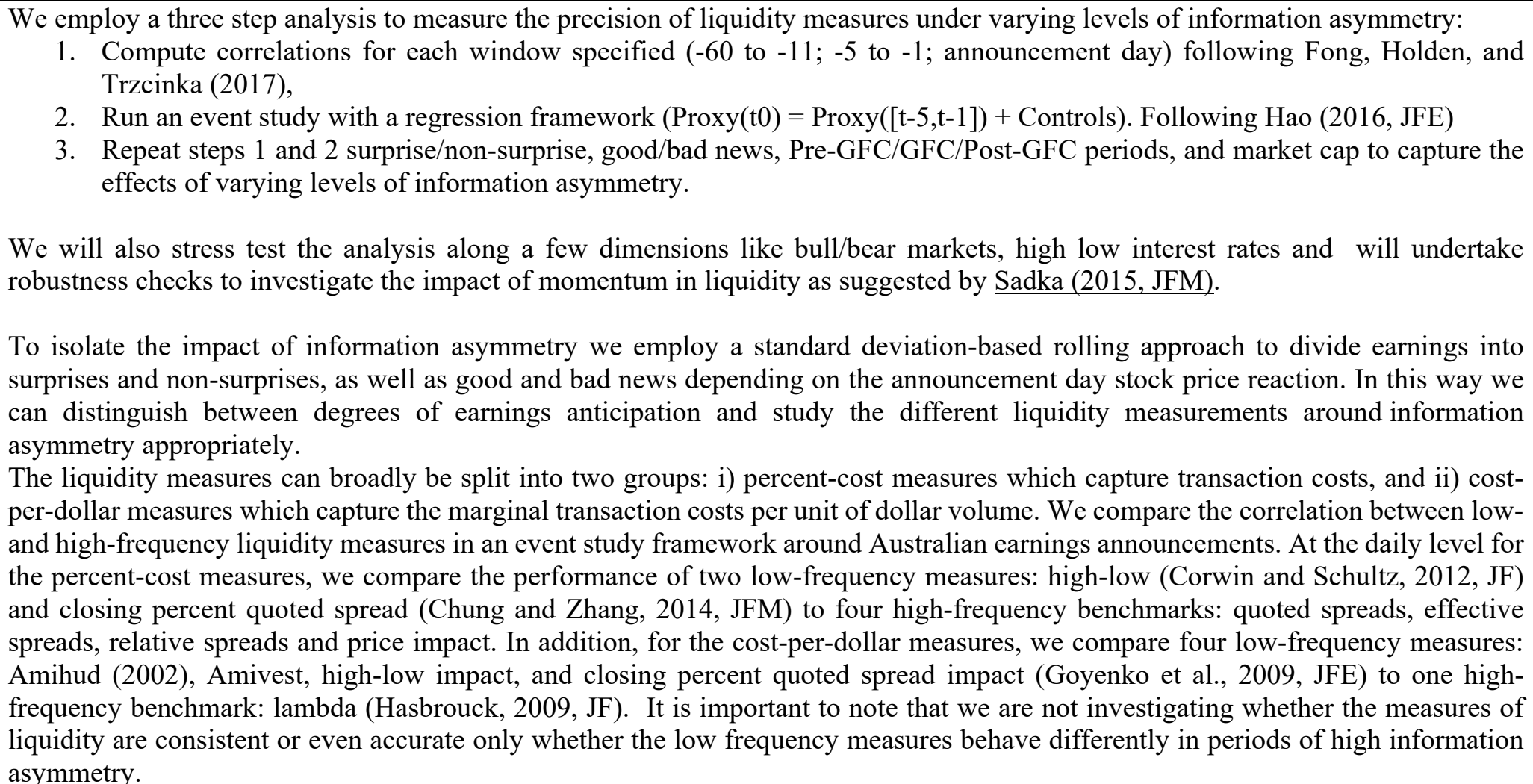 \\
\hline TWO & Two key questions \\
\hline (H) What's New? & $\begin{array}{l}\text { The availability of high frequency data and reducing computational cost has seen a proliferation of high frequency liquidity measures } \\
\text { in the literature. There is some evidence that low frequency measures are adequate however it is unclear whether this finding is robust } \\
\text { to periods of high information asymmetry. This paper analyses the trade-off between cost and measurement precision under varying } \\
\text { levels of information. }\end{array}$ \\
\hline
\end{tabular}




\begin{tabular}{|l|l|}
\hline (I) So What? & $\begin{array}{l}\text { It has now become essential for trading firms to host their key trading technology as close as possible to the stock exchange engines } \\
\text { in order to remain competitive and this is just to save a nano-second of computing time. Therefore saving on computational efficiency } \\
\text { of liquidity measures is likely to translate to real cost savings for trading strategies. In addition, the use of low frequency proxies for } \\
\text { high frequency measures will allow investigation of markets where high frequency data are not available. }\end{array}$ \\
\hline ONE & One bottom line \\
\hline (J) Contribution? & $\begin{array}{l}\text { This paper shows the trade-off between data frequency, computational efficiency and liquidity precision. Fong et al (2017) find that } \\
\text { low frequency measures can proxy for high but this finding may or may not be generalizable. In particular Fong et al (2017) did not } \\
\text { consider periods of high information asymmetry where data granularity may be advantageous. This project stress tests and validates } \\
\text { the Fong et al (2017) analysis under varying information asymmetry periods. }\end{array}$ \\
\hline (K) Other Considerations & Risk assessment is relatively low as data have already been sourced and it will be an interesting story regardless of the results. \\
\hline
\end{tabular}


A3: Phase I Registered Pitch - Frankenstein's Monster or the Birth of Venus?

\begin{tabular}{|c|c|c|c|}
\hline Pitcher's Name & \begin{tabular}{l|l} 
Bryan Howieson & FoR category \\
\end{tabular} & Accounting History & Date Completed \\
\hline (A) Working Title & \multicolumn{3}{|c|}{ Frankenstein's Monster or the Birth of Venus? Perceptions of the Contributions of Ball and Brown 1968} \\
\hline $\begin{array}{l}\text { (B) Basic Research } \\
\text { Question }\end{array}$ & \multicolumn{3}{|c|}{ What are the perceived contributions of B\&B 1968 to accounting theory, research and practice? } \\
\hline (C) Key paper(s) & \multicolumn{3}{|c|}{$\begin{array}{l}\text { R. Ball \& P. Brown, 2014, "Ball and Brown (1968): A Retrospective", The Accounting Review, 89(1), pp. } 1-26 . \\
\text { P. Brown, 2013, "Introduction", in P. Brown, Financial Accounting and Equity Markets: The Selected Essays of Philp Brown, New } \\
\text { York: Routledge, pp. } 1 \text { - 23. } \\
\text { P. Brown, 1989, "Invited Remarks: Ball and Brown [1968]", Journal of Accounting Research, 27, Supplement, pp. } 202-217 .\end{array}$} \\
\hline (D) Motivation/Puzzle & \multicolumn{3}{|c|}{$\begin{array}{l}\text { The motivation is to use the celebration of the } 50^{\text {th }} \text { anniversary of B\&B } 1968 \text { to document the nature and extent of the contribution of } \\
\text { that paper beyond the self-reported reflections of its authors. B\&B } 1968 \text { is well recognised among accounting researchers of capital } \\
\text { markets but its impact upon accounting practice and its more general influence on accounting thought are not well documented. }\end{array}$} \\
\hline THREE & \multirow{2}{*}{\multicolumn{3}{|c|}{$\begin{array}{l}\text { Three core aspects of any empirical research project i.e. the "IDioTs" guide } \\
\text { To extend PB and RB's retrospective papers beyond their own perceptions to explore those of other scholars (both adherents and non- } \\
\text { adherents) and standard-setters/practitioners. B\&B } 1968 \text { represents a sea change in accounting research relative to the so-called } a \\
\text { priori research that preceded it, but it would be valuable to know more about the perceived boundaries of this methodology, to explore } \\
\text { whether it has reached its limits, and to what extent, if any, it has impacted upon the practice of accounting. For example, this study } \\
\text { might discover that the methodology introduced largely by B\&B } 1968 \text { to accounting research has inadvertently incentivised other } \\
\text { researchers to adopt alternate methodologies as a reactionary response to what they perceived as threats from, or limitations of, the } \\
\text { B\&B } 1968 \text { methodology. This idea is reflected in the working title of the paper. }\end{array}$}} \\
\hline (E) Idea? & & & \\
\hline (F) Data? & \multicolumn{3}{|c|}{$\begin{array}{l}\text { (1) What data do you propose to use? Data will be the content of transcripts from which 'themes' are generated about the perceptions } \\
\text { of 'informed' accounting scholars and practitioners. } \\
\text { (2) What sample size do you expect? The key objective is to get sufficient breadth of perspectives across scholars, standard-setters } \\
\text { and practitioners, not only in Australia but also internationally. An important sign of a sufficient sample would be the presence of } \\
\text { theme saturation, i.e., a point at which interviews no longer generate 'new' themes. It is not possible to say ex ante how many } \\
\text { interviews this might take but realistically I would anticipate conducting between } 20 \text { to } 30 \text { interviews. } \\
\text { (3) Data Sources? A purposive sampling approach will be adopted to identify potential interviewees. Interviewees are to be identified } \\
\text { based on (a) whether they are likely to be informed enough about B\&B } 1968 \text { (e.g., do they have a sufficient familiarity with the } \\
\text { accounting literature?; were they participants in the relevant debates?) and (b) could they in principle have been impacted by B\&B } \\
1968 \text { (e.g., a standard-setter who could be informed by the findings of event study based research)? Interviewees will be asked to } \\
\text { suggest other potential interviewees (with an explanation as to why they believe they would be appropriate). The initial strategy for } \\
\text { identifying interviewees is to start with two who are 'historically' informed - Steve Zeff and Graeme Dean. Starting with a historical } \\
\text { context will assist in ensuring a broad approach is taken to identifying interviewees and an added bonus is that both Zeff and Dean } \\
\text { are very well-connected in terms of their understanding of who would be key players in the B\&B1968 story. }\end{array}$} \\
\hline
\end{tabular}




\begin{tabular}{|c|c|}
\hline & $\begin{array}{l}\text { (4) Will there be any problem with missing data/observations? Key themes could remain unidentified if there is an insufficient breadth } \\
\text { to the range of interviewees or ineffective interviewing technique. } \\
\text { (5) Will your "test" variables exhibit adequate ("meaningful") variation to give good power? Quality/reliability of data? Ensuring a } \\
\text { breadth of both 'adherents' and 'non-adherents' to the B\&B } 1968 \text { methodology (as well as a balance between academic and non- } \\
\text { academic interviewees) should assist in providing sufficient variation in the data. Interviewees will be given the opportunity to review } \\
\text { the transcripts of their interviews for verification and elaboration where necessary. } \\
\text { (6) Other data obstacles? The primary data obstacle is likely to be gaining access to relevant interviewees. This is discussed further } \\
\text { below in risks as part of "Other Considerations". }\end{array}$ \\
\hline (G) Tools? & $\begin{array}{l}\text { A qualitative approach is to be adopted employing semi-structured interviews. Interviews will be conducted face-to-face, by telephone, } \\
\text { or by Skype. Thematic analysis of the interviews will be undertaken with the assistance of the NVivo software tool. Although the } \\
\text { objective is to have the data drive the identification of themes, the analysis of the data may be informed by a theoretical structure } \\
\text { grounded in an understanding of the diffusion of innovations. }\end{array}$ \\
\hline TWO & Two key questions \\
\hline (H) What's New? & $\begin{array}{l}\text { The novelty is primarily in extending our understanding of the contribution of B\&B } 1968 \text { beyond that of its impact upon the field of } \\
\text { capital markets research. Interviewing a breadth of parties is likely to reveal unexpected ways in which B\&B } 1968 \text { has impacted on } \\
\text { accounting research and practice. }\end{array}$ \\
\hline (I) So What? & $\begin{array}{l}\text { The objective of the special issue of the Pacific Basin Finance Journal is to celebrate the considerable significance of B\&B } 1968 \text {. } \\
\text { Our understanding of the quantum of the nature and breadth of this contribution will be truncated if it is understood only within the } \\
\text { relatively narrow confines of capital markets/quantitative academic research. }\end{array}$ \\
\hline ONE & One bottom line \\
\hline (J) Contribution? & $\begin{array}{l}\text { The primary evidence of the impact of B\&B } 1968 \text { are the self-reported reflections published by B\&B. This study would supplement } \\
\text { that evidence by providing the perceptions of other, arguably 'independent', parties who include potential non-adherents of the B\&B } \\
1968 \text { methodology and the context of accounting practice which has not been addressed in the B\&B reflective papers. }\end{array}$ \\
\hline (K) Other Considerations & $\begin{array}{l}\text { Target Journal: The proposal has been generated for a special issue of the Pacific Basin Finance Journal. } \\
\text { "Risk" assessment: As noted above, a serious risk is being unable to access interviewees (this is anticipated to be a particular problem } \\
\text { with the 'non-supporters' who may feel their views are in some way irrelevant). I am hoping to manage this risk in part by leveraging } \\
\text { off 'friendly' colleagues who can vouch for the importance of interviewee participation. } \\
\text { Ethics clearance will be required. It is not anticipated that this will be a significant hurdle and it is proposed to identify in any published } \\
\text { paper who the interviewees were but not link their names to any specific quotations. } \\
\text { Other risks include: (a) obtaining funds to pay for the transcription of interviews (this is anticipated to be somewhere between } \$ 3,000 \\
\text { and } \$ 4,000 \text { depending upon the number and length of interviews); (b) failure of digital recording equipment, (c) given } 2018 \text { is a } \\
\text { 'celebratory' year for the B\&B } 1968 \text { paper, there is a possibility that some other researcher may also review the contribution of B\&B. } \\
\text { Size of team: Sue Wright has agreed to act as a 'sounding board' throughout the project. }\end{array}$ \\
\hline
\end{tabular}


Is the scope appropriate? The scope is acknowledged to be broad at this initial stage but this reflects the exploratory nature of the research question. The scope will become more focussed with feedback from project reviewer and after the preliminary analysis of the interviews. 


\section{A4: Phase I Registered Pitch - Backdoor Market Listings}

\begin{tabular}{|c|c|c|c|c|c|}
\hline Pitcher's Name & $\begin{array}{llll}\text { Larelle (Ellie) Chapple } & \text { (QUT } & \text { Business } \\
\text { School) and Victoria } & \text { Clout } & \text { (UNSW } \\
\text { Business School) } & & \end{array}$ & & $1501 \& 1502$ & Date Completed & $\begin{array}{l}\text { 6/6/2017 } \\
\text { Revised 22/09/2017 }\end{array}$ \\
\hline (A) Working Title & \multicolumn{5}{|c|}{ The high road or the low road? The information environment around backdoor market listing: A Pitch } \\
\hline $\begin{array}{l}\text { (B) Basic Research } \\
\text { Question }\end{array}$ & \multicolumn{5}{|c|}{$\begin{array}{l}\text { Are post-earnings announcement drifts different for reverse merger (or so called backdoor listing) compared to a conventional Initial } \\
\text { Public Offering (IPO) listing? }\end{array}$} \\
\hline (C) Key paper(s) & \multicolumn{5}{|c|}{$\begin{array}{l}\text { Francis, Lafond, Olsson and Schipper (2007) Information uncertainty and Post-Earnings-Announcement-Drift, Journal of Business } \\
\text { Finance and Accounting, 34: 403-433. } \\
\text { Bernard and Thomas (1990) Evidence that stock prices do not fully reflect the implications of current earnings for future earnings, } \\
\text { Journal of Accounting and Economics, 13: 305-340. } \\
\text { Lam and Chan (2016) Long-run performance of backdoor-listed firms, JASSA, 2: 6-17. }\end{array}$} \\
\hline (D) Motivation/Puzzle & \multicolumn{5}{|c|}{$\begin{array}{l}\text { Backdoor listings are essentially cases of unregulated "reverse" takeover involving a listed "shell" company, which allow a non-listed } \\
\text { counterpart an expedient means to achieve share market listing. The Australian market regulator, Australian Investments and } \\
\text { Securities Commission (ASIC) has an aversion to backdoor listings - the perception is that such listings provide a pathway for firms } \\
\text { that desire less scrutiny compared to firms that chose an IPO. As such, these listings might result in a poorer information environment } \\
\text { for investor decision-making. There is a lack of evidence testing such a view, which motivates the current proposal. }\end{array}$} \\
\hline THREE & \multicolumn{5}{|c|}{ Three core aspects of any empirical research project i.e. the "IDioTs" guide } \\
\hline (E) Idea? & \multicolumn{5}{|c|}{$\begin{array}{l}\text { Prior research persists in its failure to explain the existence of post-earnings announcement drift (PEAD). We seek to investigate } \\
\text { whether there is a difference in post-earnings announcement drift between firms where the amount and quality of publically available } \\
\text { information about a firm is low, i.e. backdoor listed firms, and compare them to IPO listed firms, where we expect the information } \\
\text { environment is superior (due, inter alia, to the prevailing IPO regulation). If investors become overconfident, drift occurs as investors } \\
\text { weight more highly their private information over public information such as earnings announcements. Through the agency of } \\
\text { comparing back door vs IPOs, we investigate whether under-confidence through limited public information has a negative effect on } \\
\text { PEAD in reverse takeovers. Prior research suggests that the data used and the type of research design will yield significant results. }\end{array}$} \\
\hline (F) Data? & \multicolumn{5}{|c|}{$\begin{array}{l}\text { Australian data - } 400 \text { back-door listed firms during the period } 2001 \text { to } 2016 \text {, matched by size and industry with } 800 \text { IPO listed firms. } \\
\text { Earnings announcement event study. We will obtain the share price and corporate governance data from SIRCA AusEquities and } \\
\text { Corporate Governance database. The method of listing, backdoor or IPO, will be hand-collected from media releases, newspaper } \\
\text { articles and SIRCA's Australian Company Announcement database. Interviews will be conducted with high value stakeholder to } \\
\text { inform the research design. Research funding associated with qualitative research interviews, travel, transcription and data collection } \\
\text { and analysis required will be sought. }\end{array}$} \\
\hline & \multicolumn{5}{|c|}{ We will use the following model, used extensively in prior literature, where we have added an indicator variable for backdoor listing: } \\
\hline
\end{tabular}




\begin{tabular}{|c|c|}
\hline & $\begin{array}{l}C A R_{z j}=\alpha_{0}+\alpha_{1} U E_{i j}+\alpha_{2} B K D+\alpha_{3} B K D * U E_{z j}+\alpha_{4} E Q_{i-1 j}+\alpha_{5} E Q_{i-1 j} * U E_{z j}+\alpha_{6} S I Z E_{z j}+\alpha_{7} S I Z E_{z j} * U E_{z j}+\alpha_{8} C G_{j} \\
\qquad+\varepsilon_{z j} \\
\text { where } C A R_{z j} \text { is the cumulative abnormal return estimated for a } 60 \text {-day window after the annual earnings announcement } z \text { for firm } j \text {, } \\
\text { and } U E_{z j} \text { is a measure of the unexpected earnings using analyst forecasts of the } z \text { earnings announcement for firm } j, B K D \text { is an } \\
\text { indicator variable which takes a value of one if a firm was backdoor listed and zero otherwise, } E Q_{i-1 j} \text { is a measure of the earnings } \\
\text { quality of firm } j \text { in period } i-1, S I Z E_{z j} \text { is measured as the market value of equity on the } 45^{\text {th }} \text { day prior to the earnings announcement } \\
\text { for year } z ; C G_{j} \text { is a vector of corporate governance measures as suggested in prior literature for firm } j . \text { We use established measures } \\
\text { of earnings quality. }\end{array}$ \\
\hline TWO & Two key questions \\
\hline (H) What's New? & $\begin{array}{l}\text { In the spirit of Ball and Brown (1968) we seek to investigate a contemporary accounting information issue and its association with } \\
\text { asset prices. See Figure } 1 .\end{array}$ \\
\hline (I) So What? & $\begin{array}{l}\text { Providing evidence to ASIC, given ASIC's assertions that backdoor listing firms have weaker corporate governance and whether the } \\
\text { market information releases provided by these firms are less useful to market participants compared to those issued by IPO listed } \\
\text { firms. Evidence from this study will help either affirm the ASIC view or give it food for thought to moderate or even change its stance } \\
\text { on back door listings. }\end{array}$ \\
\hline ONE & One bottom line \\
\hline (J) Contribution? & $\begin{array}{l}\text { To date there has been scant examinations of post-earnings announcement drift in Australia, even though according to anecdotal } \\
\text { evidence from the finance industry drift does exist in Australia. Little is also known about how corporate governance interacts with } \\
\text { PEAD. The CEOs of BKD firms, similar to securities class action firms, have a high incidence of dominate CEOs. As per prior } \\
\text { research these dominate CEOs tend to influence the nomination committee and surround themselves with directors of their choice } \\
\text { thus potentially influencing the corporate disclosure quality. }\end{array}$ \\
\hline (K) Other Considerations & $\begin{array}{l}\text { The research team assembled has the appropriate skills and prior expertise in the areas of capital markets research and a prior track } \\
\text { record of papers investigating into regulatory and corporate governance issues. There is a potential that some of backdoor listed firm } \\
\text { sample will have zero analyst coverage throughout the sample period and these firms would be removed from the sample as we would } \\
\text { not be able to calculate unexpected earnings (UE). } \\
\text { Target Journal(s)? Pacific-Basin Finance Journal Special Issue } \\
\text { Conferences: AFAANZ } 2017 \text { Adelaide Behavioural Finance SIG pitch paper presentation and AFAANZ } 2018 \text { Conference Auckland } \\
\text { full paper presentation. } \\
\text { The qualitative interview component would require an ethics clearance process. There is a medium risk of competitors in the area } \\
\text { investigating post-earnings announcement drift. Hand-collection of the sample of interest provides a barrier to competitor entry. } \\
\text { The paper is of an appropriate scope for a scholarly academic research paper. }\end{array}$ \\
\hline
\end{tabular}




\section{A5: Phase I Registered Pitch - Climate Change}

\begin{tabular}{|c|c|c|c|c|}
\hline Pitcher's Name & & Capital Markets & Date Completed & 18 July 2017 \\
\hline (A) Working Title & \multicolumn{4}{|c|}{ Winds of change: Market response to change in government commitment to combatting climate change } \\
\hline $\begin{array}{ll}\text { (B) Basic Research } \\
\text { Question }\end{array}$ & \multicolumn{4}{|c|}{ Does firm-level climate risk temper the association between government commitment to combatting climate change and stock price? } \\
\hline (C) Key paper(s) & \multicolumn{4}{|c|}{$\begin{array}{l}\text { Berkman, H., Jona, J., Lim, K., and N. Soderstrom. (2017). Do Market Valuations Incorporate Climate Risk? Available at SSRN: } \\
\text { https://ssrn.com/abstract=2775552 } \\
\text { Berkman, H., Cole, R., and L. Fu. (2010). Political Connections and Minority-Shareholder Protection: Evidence from Securities- } \\
\text { Market Regulation in China. The Journal of Financial and Quantitative Analysis, 45(6), 1391-1417. } \\
\text { Ferguson, A., and P. Lam. (2016). Government policy uncertainty and stock prices: The case of Australia's uranium industry. Energy } \\
\text { Economics 60: 97-111. } \\
\text { Li, C., Luo, J., and N. Soderstrom. (2017). Market Response to Regulatory Costs Related to Haze. Journal of Accounting and Public } \\
\text { Policy. 36(3): 201-219. } \\
\text { Noreen, E., and J. Sepe. (1981). Market Reactions to Accounting Policy Deliberations: The Inflation Accounting Case. The } \\
\text { Accounting Review, 56(2), 253-269. }\end{array}$} \\
\hline (D) Motivation/Puzzle & \multicolumn{4}{|c|}{$\begin{array}{l}\text { Climate change and carbon emissions were "the most significant overall environmental factor" for socially-minded investors in the } \\
\text { U.S., with institutional investor assets reaching } \$ 2.15 \text { trillion in } 2015 \text { (Chandler, 2017). However, President Trump's intentions to roll } \\
\text { back environmental policies run counter to growing demand from shareholders for firms to consider climate risks in their strategies. } \\
\text { Trump's approach is dramatically different from that of President Obama, who supported global efforts to address climate change. } \\
\text { Our project exploits this variation in approach to investigate the importance to shareholders of government commitment to combatting } \\
\text { climate change. } \\
\text { A tension in our analysis arises because there are state and local level governmental commitments to combatting climate change that } \\
\text { may circumvent any Federal regulations. For example, the State of California has vowed to use state-level mechanisms to implement } \\
\text { the } 2016 \text { Paris agreement on Climate Change (The LA Times, June } 22017 \text { ). }\end{array}$} \\
\hline \multicolumn{5}{|l|}{ THREE } \\
\hline (E) Idea? & \multicolumn{4}{|c|}{$\begin{array}{l}\text { We propose to use event-study methodology to examine whether the level of government commitment to combatting climate change } \\
\text { has an impact on the value of firms and whether this impact depends on the firms' level of climate risk. We use several exogenous } \\
\text { shocks (events): the Paris agreement, the surprise election of Trump as president, the choice of a climate change denier as minister of } \\
\text { energy, the announcement of budget cuts for the EPA, and others to investigate these issues. } \\
\text { To isolate the effect of government commitment we include non-US firms in the sample who are listed in the US but would not be } \\
\text { directly subject to US climate change policy implementation. }\end{array}$} \\
\hline
\end{tabular}




\begin{tabular}{|c|c|}
\hline (F) Data? & $\begin{array}{l}\text { (1) Setting: we focus US listed firms (domestic and foreign). We propose to form } 4 \text { portfolios based upon climate risk and expected } \\
\text { impact of US government commitment to climate change: (a) High climate risk US firms; (b) Low climate risk US firms, (c) High } \\
\text { climate risk non-US firms; and (d) Low climate risk non-US firms. } \\
\text { (2) All US firms are in the Russell 3000. The non-US firms are large non-US companies that have a US listing. Our study covers } 2 \\
\text { fiscal years (2015-2016) with an estimated sample size of about 5,000 firm-year observations. } \\
\text { (3) We use a calendar time portfolio strategy (time series) to study a cross-sectional contrast (i.e. high vs. low level of climate risk). } \\
\text { (4) Data Sources? We use a publicly available measure of firm-specific exposure to climate risk based on 10-K disclosures for the } \\
\text { climate risk measure. We use the standard financial data from Compustat and CRSP } \\
\text { (5) The data are relatively clean, publically available and should allow for a powerful test in line with related studies. } \\
\text { (6) Potential weakness in our sample: non-US firms listed in US might be active in US and 'benefit' in the same way from lax } \\
\text { environmental policies as US firms. This can potentially be address by examining country of origin and amount US operations for the } \\
\text { non-US firms. }\end{array}$ \\
\hline (G) Tools? & $\begin{array}{l}\text { We estimate time series models where the dependent variable is the return on a hedge portfolio that is long (say) US high climate } \\
\text { risk firms and short (say) US low climate risk firms. The return on the hedge portfolio is a function of typical factors (market, size, } \\
\text { value, momentum). Our interest is in event-dummies that are } 1 \text { on the event days. We expect this dummy to be positive on the day } \\
\text { of Trump's election and on the day the EPA cuts were announced. We have similar predictions for the long-short portfolio after } \\
\text { subtracting the return of a control hedge portfolio (non-US high climate risk firms - non-US low climate risk firms). We will } \\
\text { consider other dimensions to form long-short portfolios, e.g. polluters vs. non-polluters, and firms with high vs low carbon } \\
\text { emissions (as identified by Heede 2014). } \\
\text { Our data allow us to focus on different } 3 \text { specific types of climate change risk: (1) Physical, (2) Regulatory and (3) Renewable Fuels } \\
\text { and Technology. We expect to find stronger effects for companies with higher regulatory risk followed by firms with higher } \\
\text { renewable fuels and technology risk because these risk are most directly related to likely actions following the Paris agreement. } \\
\text { We choose this method because with clustered events (i.e. events that affect all sample firms at the same time), there is a severe } \\
\text { problem of cross correlation of the error terms. Models such as GLM are unable to correct for the resulting bias in t-statistics. With a } \\
\text { large sample such as ours, it will only take a small cross correlation to cause extreme distortions in the t-statistics (Mitchell and } \\
\text { Stafford, 2000). } \\
\text { In addition to standardizing our measures by industry, we will run models within specific industries (e.g., high climate risk and low } \\
\text { climate risk firms within a single industry). }\end{array}$ \\
\hline & \\
\hline
\end{tabular}




\begin{tabular}{|l|l|}
\hline (H) What's New? & $\begin{array}{l}\text { Our fundamental question of how the market views government signals about intended policy, particularly in the context of climate } \\
\text { change, has not been explored before. Further, we employ a unique firm-level measure of climate risk which allows us to exploit } \\
\text { expected cross sectional variation in the market's response. }\end{array}$ \\
\hline (I) So What? & $\begin{array}{l}\text { Climate change is a world-wide problem and has been the focus of international agreements and government policies. While business } \\
\text { impacts contribute to climate change they also are the engine that drives economies to produce resources that could be used to combat } \\
\text { climate change. Government policy is at the interface between business and climate change and therefore understanding the how } \\
\text { governmental approaches to climate change policies affect capital markets is extremely important. }\end{array}$ \\
\hline ONE & $\begin{array}{l}\text { We are implementing a novel firm-level climate risk measure into the finance literature. We are also linking business to politics and } \\
\text { the policy environment in a new way. }\end{array}$ \\
\hline (K) Contribution? & $\begin{array}{l}\text { - Target journal PBFJ } \\
\text { - We have a diverse group of authors with expertise in financial accounting, finance and sustainability research. } \\
\text { - We view the risk to success for this project to be low because results will be interesting irrespective of the outcome. }\end{array}$ \\
\hline
\end{tabular}


A6: Phase I Registered Pitch - Carbon Tax Policy

\begin{tabular}{|c|c|c|c|c|c|}
\hline Pitcher's Name & Han Pan Linnenluecke Smith & FoR category & 1502 & Date Completed & $\begin{array}{l}\text { May } 2017 \\
\text { Updated July } 2017\end{array}$ \\
\hline (A) Working Title & \multicolumn{5}{|c|}{ Wealth Effects of Carbon Tax Policy in Australia } \\
\hline $\begin{array}{l}\text { (B) Basic Research } \\
\text { Question }\end{array}$ & \multicolumn{5}{|c|}{ Examine the announcement of the carbon tax in Australia, separating out the news effects and valuation effects. } \\
\hline (C) Key paper(s) & \multicolumn{5}{|c|}{$\begin{array}{l}\text { Ball, R., \& Brown, P. (1968). An empirical evaluation of accounting income numbers. Journal of Accounting Research, 159-178. } \\
\text { Barraclough, K., Robinson, D. T., Smith, T., \& Whaley, R. E. (2013). Using option prices to infer overpayments and synergies in } \\
\text { M\&A transactions. Review of Financial Studies, 26(3), 695-722. }\end{array}$} \\
\hline (D) Motivation/Puzzle & \multicolumn{5}{|c|}{$\begin{array}{l}\text { There is an identification problem when announcements have unresolved uncertainty. In this situation the Ball and Brown (1968) } \\
\text { methodology cannot be applied because the price on announcement contains an outcome probability parameter as well as outcome } \\
\text { price parameters. We propose an approach that can be used to analyse announcements which contain unresolved uncertainty. The } \\
\text { approach uncovers the probability and outcome parameters and enables the price change on announcement to be split into news effects } \\
\text { and valuation effects. We apply this approach to the announcement of the introduction of a carbon tax in Australia. The news effects } \\
\text { of Australia taking a strong stance on climate change is important both economically for markets and politically for policy makers } \\
\text { who are interested in making the economy robust to threats likely to be present in the coming decades. The valuation effects of the } \\
\text { proposed carbon tax are of crucial importance for firms and shareholders as they affect long run profitability and viability. }\end{array}$} \\
\hline THREE & \multirow{2}{*}{\multicolumn{5}{|c|}{$\begin{array}{l}\text { Three core aspects of any empirical research project i.e. the "IDioTs" guide } \\
\text { Announcements that have unresolved uncertainty mean that there is an identification problem when the Ball and Brown (1968) event } \\
\text { study methodology is applied. This is because the price change contains information on the outcome probability as well as the outcome } \\
\text { price parameters. The price on announcement can be written as } \mathrm{P}=\mathrm{p} \mathrm{P}^{\mathrm{S}}+(1-\mathrm{p}) \mathrm{P}^{\mathrm{F}} \text {, where } \mathrm{p} \text { is the probability of a successful outcome } \\
\text { and PS is the price if the outcome is a success and } \mathrm{P}^{\mathrm{F}} \text { is the price if the outcome is a fail. Thus we see the identification issue is that } \\
\text { we have one price and three parameters. It is possible to complete the equation set by using options on the announcement stock. This } \\
\text { introduces further parameters in the form of the volatility for the success and fail outcomes. In total there are } 5 \text { parameters to estimate } \\
\text { and therefore at least four option prices are needed to identify the equation system. }\end{array}$}} \\
\hline (E) Idea? & & & & & \\
\hline (F) Data? & \multicolumn{5}{|c|}{$\begin{array}{l}\text { We propose to use stock and option prices on stocks that were subject to the carbon tax. These prices will be collected as at the date } \\
\text { of the announcement. } \\
\text { All stocks that were affected by the carbon tax. However not all these firms will have traded options so that will reduce the sample } \\
\text { size. } \\
\text { No, it is a cross-sectional study at the date of the announcement. } \\
\text { The data are readily available from commercial sources such as Datastream and Bloomberg. }\end{array}$} \\
\hline
\end{tabular}




\begin{tabular}{|c|c|}
\hline & $\begin{array}{l}\text { There are a lot of tricks for young players in dealing with option data but we have an experience research team that is skilled in these } \\
\text { issues. The tricks include taking the raw data and getting it usable form taking into account, time to experiation, exercise price, volume } \\
\text { and bid/ask vs transaction prices. } \\
\text { Yes, we will have a substantial cross section of firms across various industry groups. Options are written on large firms with high } \\
\text { share volume and include both carbon intensive firms and non-carbon intensive firs so that will enhance the variation across firms. } \\
\text { The main obstacle is whether firms have options written on them and whether there are sufficient option series for the purposes of } \\
\text { identification. }\end{array}$ \\
\hline (G) Tools? & $\begin{array}{l}\text { The research will require the estimation of five parameters from five or more stock and option equations. This is a standard numerical } \\
\text { procedure and the researchers will provide the R code as part of the appendix of the paper. }\end{array}$ \\
\hline TWO & Two key questions \\
\hline (H) What's New? & $\begin{array}{l}\text { What's new is the solving of the identification problem of announcements that involve unresolved uncertainty. The estimation of the } \\
\text { probability and outcome price parameters means that researchers will be able to separate wealth and news effects of announcements. }\end{array}$ \\
\hline (I) So What? & $\begin{array}{l}\text { Announcement studies that have been conducted when there is outcome uncertainty have confounded news effects and valuation } \\
\text { effects. They have taken the price change on announcement as the wealth effect but this ignores the fact that the announcement price } \\
\text { is a weighted probability of event success and outcomes. Barraclough et al. (2013) demonstrate that the traditional approach } \\
\text { understates bidder gain effects in the takeover situation and that correctly identifying the underlying probability and outcome } \\
\text { parameters reveals that the bidder and target share the wealth effects of takeovers equally. Being able to disentangle the news effect } \\
\text { of the Australian Government taking a strong stance on climate change and the valuation effects of the specific proposed carbon tax } \\
\text { provide insight to policy makers and investors alike. }\end{array}$ \\
\hline ONE & One bottom line \\
\hline (J) Contribution? & $\begin{array}{l}\text { We provide a template for conducting an announcement study when their announcement involves unresolved uncertainty. } \\
\text { We will also compare our methodology with an intervening events methodology that has been discussed in the literature. The } \\
\text { intervening event methodology does not allow the researcher to infer news and value effects on announcement but rather requires } \\
\text { further intervening events (eg news reports about likely voting patterns in parliament) to provide further price observations and thus } \\
\text { allow the calculation of the unknown parameters. Since there are } 3 \text { unknown parameters, there would need to be } 3 \text { intervening events. }\end{array}$ \\
\hline (K) Other Considerations & $\begin{array}{l}\text { We intend to collaborate with researchers from University of Tasmania and University of Otago as they bring significant programming } \\
\text { skills. } \\
\text { Our aim is to publish in the prestigious Pacific Basin Finance Journal } \\
\text { Risk of being beaten by a competitor or of obsolescence is low. } \\
\text { No serious challenges that cannot be handled by the research team. } \\
\text { The approach is very general but the application of the approach to the Australian Carbon Tax announcement is very focused. }\end{array}$ \\
\hline
\end{tabular}


A7: Phase I Registered Pitch - Management Earnings Forecasts

\begin{tabular}{|c|c|c|c|c|}
\hline Pitcher's Name & $\begin{array}{l}\text { Hiroyuki Aman, Wendy Beekes, Millicent } \\
\text { Chang and Marvin Wee }\end{array}$ & FoR category & Date Completed & 27 July 2017 \\
\hline (A) Working Title & \multicolumn{4}{|c|}{ The properties of management forecasts and their relationship with analyst forecasts in Japan } \\
\hline (B) Basic Research Quest & \multicolumn{4}{|c|}{ Does the information environment influence the inter-relationship between management forecasts and analyst forecasts? } \\
\hline (C) Key paper(s) & \multicolumn{4}{|c|}{$\begin{array}{l}\text { AGUILERA, R. V.; K. A. DESENDER; M. L.-P. LAMY and J. H. LEE. “The governance impact of a changing investor landscape." } \\
\text { Journal of International Business Studies } \mathbf{4 8}(2017): 195-221 . \\
\text { OTA, K. "The Value Relevance of Management Forecasts and Their Impact on Analysts' Forecasts: Empirical Evidence From Japan." } \\
\text { Abacus } 46 \text { (2010): 28-59. } \\
\text { KATO, K.; D. J. SKINNER and M. KUNIMURA. "Management Forecasts in Japan: An Empirical Study of Forecasts that Are } \\
\text { Effectively Mandated." The Accounting Review } \mathbf{8 4}(2009): 1575-1606 .\end{array}$} \\
\hline (D) Motivation/Puzzle & \multicolumn{4}{|c|}{$\begin{array}{l}\text { Management forecasts of earnings are essentially mandatory in Japan, making this a unique environment to study the link between } \\
\text { management and analyst forecasts in listed companies. Financial analysts rely heavily on the forecasts provided by management to } \\
\text { formulate their own forecasts. However in cases where the credibility of management forecasts' is in question, financial analysts are } \\
\text { likely to place less reliance on management forecasts and to adjust their forecasts appropriately. Analysts are expected to assess } \\
\text { managers' credibility based upon the accuracy of past forecasts (and timeliness of revisions made to forecasts). It would appear that } \\
\text { managers are unconcerned about reputational effects of providing biased forecasts since prior evidence shows managers tend to be } \\
\text { optimistic in their initial forecasts. There may be fewer incentives for managers to provide accurate earnings forecasts in Japan given } \\
\text { the culture of lifetime employment and the existence of complex cross-shareholding relationships within corporate groupings which } \\
\text { may facilitate the transfer of information within the group. However, with increasing levels of foreign ownership in recent times, the } \\
\text { need for transparent disclosures and more accurate forecasts is likely to be more important in Japanese firms. If managers are unable } \\
\text { to forecast earnings accurately, and analysts are found to have more precise forecasts, we consider that it is possible that managers } \\
\text { may use analysts' prior earnings forecasts to inform their own current period earnings forecast. The study will investigate the influence } \\
\text { of corporate governance and transparency in Japan on the inter-relationship between management and analyst forecasts. }\end{array}$} \\
\hline THREE & \multicolumn{4}{|c|}{ Three core aspects of any empirical research project i.e. the "IDioTs" guide } \\
\hline (E) Idea? & \multicolumn{4}{|c|}{$\begin{array}{l}\text { Our study examines whether the credibility of management forecasts affects the interdependence between management and analysts' } \\
\text { earnings forecasts. While analysts seek to update their forecasts when management forecasts are released (and updated), their response } \\
\text { to management forecasts depends on analysts' ability to evaluate the credibility of management forecasts. Similarly, managers' use } \\
\text { of the information available in analyst forecasts depends on how credible they perceive the information to be (as assessed by their } \\
\text { prior forecasting ability and their knowledge of the sector as a whole). Therefore, the interrelationship between management and } \\
\text { analyst forecasts is expected to be a function of forecast credibility. Management forecast credibility can be affected by the company's } \\
\text { corporate governance structures, forecast difficulty relating to the sector and the use of executive compensation contracts. Analyst } \\
\text { forecast credibility can be affected by the number of analysts following the firm and the prior track record of the analysts in forecasting } \\
\text { (in terms of accuracy and bias). We hypothesise that analysts' adjustments or responses to any management forecast news are } \\
\text { conditioned on the credibility of the management disclosure (H1). This extends the work by Ball and Brown (1968), by examining }\end{array}$} \\
\hline
\end{tabular}




\begin{tabular}{|c|c|}
\hline & $\begin{array}{l}\text { the effects of credibility on the relationship between analyst response and earnings expectation. Where managers have previously } \\
\text { found it difficult to forecast earnings accurately (and analysts' forecasts have been more accurate), it is possible that managers use } \\
\text { analyst forecasts to inform their own current year earnings forecast. Therefore, we posit that the accuracy of management forecasts is } \\
\text { dependent on the credibility of analyst forecasts (H2). } \\
\text { H1: Initial forecasts (and revisions in) analysts' earnings forecasts are positively associated with management earnings forecasts when } \\
\text { management forecasts are perceived to be more credible. } \\
\text { H2: There is a positive association between prior year analyst forecasts and management forecast revisions when analysts' forecasts } \\
\text { are more credible. }\end{array}$ \\
\hline (F) Data? & $\begin{array}{l}\text { Japanese firms are required to disclose their forecasts for next year with the current year annual earnings release. The dataset will } \\
\text { comprise annual earnings releases and management forecasts (MFs), voluntary management forecast revisions (non-periodic), analyst } \\
\text { forecasts (AFs) and revisions, and daily share price data around the management forecasts and revisions. The sample will comprise } \\
\text { firms from the } 1^{\text {st }} \text { section of the Tokyo Stock Exchange - } 1,500 \text { firms over the most recent } 10 \text { years. We will use various databases for } \\
\text { the project. Nikkei Financial Quest database for financial data. Nomura Research Institute database for MFs. CGES data for corporate } \\
\text { governance (CG) (essentially captures board size and composition, incentives for executives and share ownership structures). } \\
\text { Based upon Kato et al.'s sample about } 90 \% \text { of sample firms issue management forecasts (See, Kato et al } 2009, \mathrm{p} .1582 \text { ). For analyst } \\
\text { forecasts, Aman-Beekes-Brown's working paper use I/B/E/S from WRDS and find no problem for the Japanese data. Absolute } \\
\text { numbers for income are forecasted rather than Earnings Per Share numbers, so these must be generated using number of shares data. } \\
\text { There is a question of the accuracy of this approximation. Also could consider using IFIS data as an alternative source to I/B/E/S. } \\
\text { Analyst coverage in Japan may be smaller than that in US/UK/AU. However, the benefit of using a Japanese dataset is that a large } \\
\text { number (if not all) of firms in Japan release management forecasts. }\end{array}$ \\
\hline (G) Tools? & $\begin{array}{l}\text { The following lists the regressions models we will consider: } \\
\text { - Analyst forecasts revision = f(Management forecast revision, } \mathrm{CG} \text {, Transparency, Control variables) } \\
\text { - Properties of management forecast (Bias, Accuracy) }=\mathrm{f}(\mathrm{CG}, \text { Analyst following, Transparency, Control variables) } \\
\text { - Properties of analyst forecasts (Bias, Accuracy, Disagreement) }=\mathrm{f}(\text { Management forecast error, CG, Analyst following, } \\
\quad \text { Transparency, Control variables) } \\
\text { We will use structural equation modelling (SEM) to analyse the data. In addition, panel regressions analysis (clustered standard errors } \\
\text { by firm-month are necessary as it is the same firm being sampled) will be included. }\end{array}$ \\
\hline TWO & Two key questions \\
\hline (H) What's New? & $\begin{array}{l}\text { The novelty is using SEM to study the bi-directional relationship between MFs and AFs. Also, the potential influence that CG on the } \\
\text { inter-relationship between MF and AF. }\end{array}$ \\
\hline
\end{tabular}




\begin{tabular}{|l|l|}
\hline (I) So What? & $\begin{array}{l}\text { The requirement for management to forecast next period earnings potentially changes the role that analysts play in the provision and } \\
\text { dissemination of firm level information. }\end{array}$ \\
\hline ONE & One bottom line \\
\hline (J) Contribution? & Prior studies have not examined the effects of analyst following on the properties of MF. This was acknowledged in Kato (2009). \\
\hline (K) Other Considerations & $\begin{array}{l}\text { Is Collaboration needed/desirable? - This project will involve researchers with different but complementary skill sets. } \\
\text { Target Journal - Pacific Basin Finance Journal } \\
\text { "Risk" assessment - There has been a number of studies using the Japanese setting. However, we believe the risk is moderated due } \\
\text { to lack of availability of the CG/transparency data. } \\
\text { Is the scope appropriate? Yes. }\end{array}$ \\
\hline
\end{tabular}


A8: Phase I Registered Pitch - CEO Human Capital

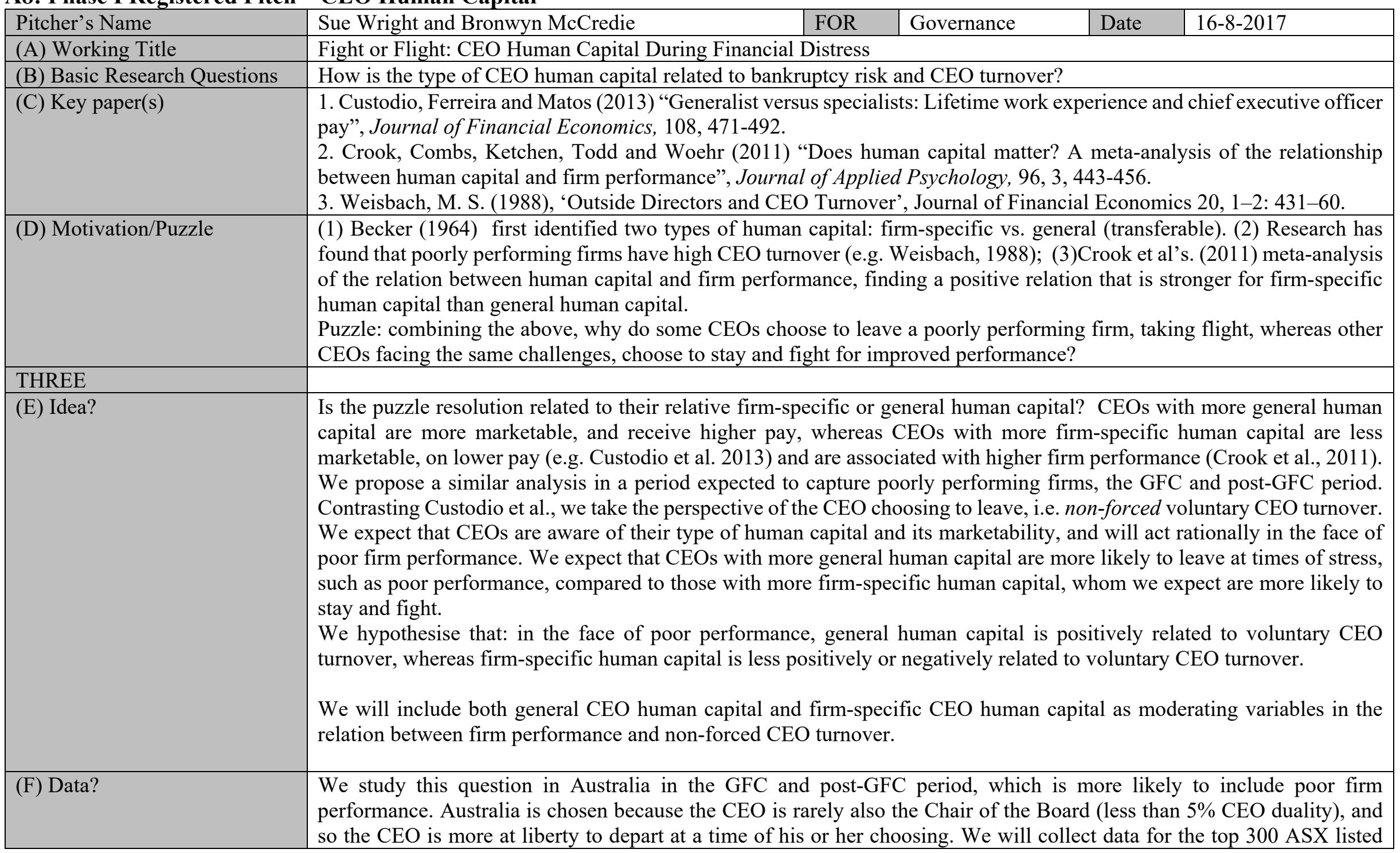




\begin{tabular}{|c|c|}
\hline & $\begin{array}{l}\text { firms from } 2007 \text { to } 2016 \text {. Data is generally available from existing databases (eg Connect4, FinAnalysis), apart from the } \\
\text { identification of voluntary CEO turnover, which needs to be hand-collected from a variety of sources including company } \\
\text { announcements, press reports and information about the CEO. General human capital is measured using CEO degrees and } \\
\text { qualifications, age and total remuneration. Firm-specific human capital is measured using tenure in the position, and } \\
\text { number of previous positions in other firms. The final selection will depend on data availability. }\end{array}$ \\
\hline (G) Tools? & $\begin{array}{l}\text { To eliminate any potential endogeneity issues a system of simultaneous equations will be employed to investigate: } 1 \text {. } \\
\text { determinants of voluntary CEO turnover, including both general and firm specific human capital (probit model); and 2. the } \\
\text { impact of CEO turnover and general and firm specific human capital on firm performance. We will follow the prior } \\
\text { literature in controlling for firm performance measures, sales, CEO duality, bankruptcy risk, CEO ownership, and include } \\
\text { year and industry fixed effects. The classification of forced versus voluntary CEO turnover will be based on factors } \\
\text { including the content and tone of the reasons for departure provided in public announcements, including the length of the } \\
\text { announcement, the availability of a replacement, the age and next role of the departing CEO. } \\
\text { The classification of general versus firm-specific CEO human capital is based on methods used in the prior literature (e.g } \\
\text { Murphy and Zabojnik, 2007: http://ssrn.com/abstract=984376). }\end{array}$ \\
\hline \multicolumn{2}{|r|}{ 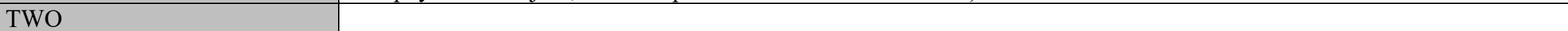 } \\
\hline (H) What's New? & $\begin{array}{l}\text { The novelty is the theoretical explanation of why some CEOs take flight and why some stay to fight; the idea of associating } \\
\text { voluntary decisions by CEOs with the nature of their human capital. That is: decisions to leave with their level of general } \\
\text { human capital; and decisions to stay with their level of firm-specific human capital. }\end{array}$ \\
\hline (I) So What? & $\begin{array}{l}\text { Choice of CEO matters. CEO remuneration is high, as is the cost of CEO replacement in the event of turnover. CEO } \\
\text { performance and remuneration are also strongly linked to firm performance. Getting a "better fix" on the "right" } \\
\text { combination of CEO skills to both hire and invest in for the firm's situation is essential for the board of directors. It also } \\
\text { assists investors and analysts who are forecasting future performance. }\end{array}$ \\
\hline \multicolumn{2}{|l|}{ ONE } \\
\hline (J) Contribution & $\begin{array}{l}\text { Enhance the corporate governance literature by providing new evidence on factors associated with voluntary CEO turnover } \\
\text { in the context of poor performance, using a unique framework that analyses the differences between CEOs with firm- } \\
\text { specific and general human capital. }\end{array}$ \\
\hline Other considerations & $\begin{array}{l}\text { The idea for this project originated in a working paper by Marion Hutchinson, "Fight or Flight: CEO Human Capital, } \\
\text { Bankruptcy Risk and Firm Performance", presented at European Accounting Association Congress 2013, Financial } \\
\text { Markets and Governance Conference 2014, AFAANZ 2015. }\end{array}$ \\
\hline
\end{tabular}


A9: Phase I Registered Pitch - Insider Trading

\begin{tabular}{|c|c|}
\hline Pitcher's Name & Allan Hodgson, Stacey Beaumont, Raluca Ratiu and Zhengling Xiong \\
\hline $\begin{array}{l}\text { (B) Basic Research } \\
\text { Question }\end{array}$ & $\begin{array}{l}\text { Does corporate insider trading reflect an anticipation of the winner/loser anomaly? For example, do insiders anticipate a break in price } \\
\text { momentum strings well before price reversion? }\end{array}$ \\
\hline (C) Key paper(s) & $\begin{array}{l}\text { (1) DeBondt W. and R. Thaler, (1985), Does the stock market over-react? Journal of Finance, 40, 793-80. } \\
\text { (2) Lakonishok, J. and Lee, I., (2001), Are insider trades informative? The Review of Financial Studies, 14(1), pp.79-111. } \\
\text { (3) Ke, B., S. Huddart, and K. Petroni, (2003), What insiders know about future earnings and how they use it: Evidence from insider } \\
\text { trades, Journal of Accounting and Economics, 35, 315-346. }\end{array}$ \\
\hline (D) Motivation/Puzzle & $\begin{array}{l}\text { How markets react to information and the relative level of arbitrage capital are important questions for market efficiency. The well- } \\
\text { known winner/loser anomaly is based upon investor psychology and market overreaction with the degree of psychological impact } \\
\text { represented by extreme portfolios earning excess returns of } 25 \% \text { over the subsequent } 3 \text { years (DeBondt and Thaler, 1985). Insiders, } \\
\text { on the other hand, have privileged access to private information and are known to contrarian trade and anticipate price and earnings } \\
\text { reversals (Lakonishok and Lee, 2001; Ke, Huddart and Petroni, 2003). From a more general perspective, there is a tension between } \\
\text { different information sets assocaited with different key market players, and we can advance our understanding of market efficency } \\
\text { and arbitrage processes, by designing empirical tests that exploits this tension. }\end{array}$ \\
\hline THREE & Three core aspects of any empirical research project i.e. the "IDioTs" guide \\
\hline (E) Idea? & $\begin{array}{l}\text { The key idea is to examine the profitability of insider trading in the context of potential "winner-loser" pressures - to see whether and } \\
\text { to what extent the well-known ability of insiders to contrarian trade on private information, counters the general market's over-reaction } \\
\text { disposition. We have several broad predictions: } \\
\text { i. Corporate insiders recognise the overreaction by traders and adjust their transaction behaviour to take advantage and earn } \\
\text { excess returns. } \\
\text { ii. Insider based contrarian selling increases well before the winner/loser portfolio price string breaks. } \\
\text { iii. There is a U-shaped functional trading and return relationship between insiders and the decile based winner/loser portfolios. } \\
\text { iv. Insiders trade upon knowledge of forthcoming accounting disclosures per Ball and Brown (1968, JAR). } \\
\text { A baseline analysis will focus on the US. At a second stage, a comparative study using an Asian market (specifically Hong Kong), } \\
\text { that differs significantly in culture and ownership structure which offers contrasting predictions. We will also examine trading and } \\
\text { return results before and after the GFC and examine if insider predictive ability was compromised (Womack, 1996, JF). }\end{array}$ \\
\hline (F) Data? & $\begin{array}{l}\text { The US market data to be used are daily stock returns sourced from CRSP and firm variables from COMPUSTAT and the UQ database } \\
\text { on insider trading for } 4,954,744 \text { insider open market transactions for } 24,811 \text { US firms during 1986-2016. For Hong Kong, we have } \\
214,006 \text { insider transactions for } 2007 \text { HK firms during } 2003-2016 \text {. }\end{array}$ \\
\hline (G) Tools? & $\begin{array}{l}\text { Winner/loser portfolios will be constructed over a three-year period and rolled over every subsequent three years (Debondt and Thaler, } \\
\text { 1985). We will measure insider returns using cumulative abnormal returns (CARs) and buy-and-hold abnormal returns (BHARs). }\end{array}$ \\
\hline
\end{tabular}




\begin{tabular}{|c|c|}
\hline & $\begin{array}{l}\text { Several different approaches to calculate abnormal returns: market adjusted, Fama-French three factor and Fama-French five factor } \\
\text { models. Insider trading activity will also be calculated by [NETSELL/BUY]/TOTAL TRANSACTIONS } \\
\text { Finally, we will run firm-portfolio year level regressions to insider returns and trading activity as a function of the winner/loser } \\
\text { portfolios using controls for:: total assets (TA) (Seyhun, 1986, JFE); book to market ratio (BM) and annual stock return to control for } \\
\text { contrarian trading tendencies (Lakonishok et al., 1994, JF, Rozeff and Zaman, 1998, JF); as well as (R\&D) (Aboody and Lev, 2000, } \\
\text { JF); and loss dummy (LOSS) (Huddart and Ke, 2007, CAR and Brochet, 2010, TAR). }\end{array}$ \\
\hline TWO & Two key questions \\
\hline (H) What's New? & $\begin{array}{l}\text { No paper is yet to research market reactions to the conditioned trading of corporate insiders, Winner and Loser portfolios, and the } \\
\text { impact of accounting variables (earnings). }\end{array}$ \\
\hline (I) So What? & $\begin{array}{l}\text { Market efficiency and the speed of reversion to fundamental values drives the integrity of markets. Should the research indicate that } \\
\text { the market has an (immediate) converse reaction to the trading of insiders then the behavioural (disposition) traits of investors are } \\
\text { negated. Corporate insider trading should then be supported but regulated and mechanisms made available to transfer that information } \\
\text { to markets. If not, then evidence is provided that the behaviour of the market over-powers private information trading and investors } \\
\text { should be informed that this behaviour is a non-diversifiable longer term risk. Investors, aware of the behaviour risk and its relation } \\
\text { to accounting factors will now be better informed when setting up risky trading strategies. }\end{array}$ \\
\hline ONE & One bottom line \\
\hline (J) Contribution? & $\begin{array}{l}\text { The paper will contribute to behavioural finance and the trade-off between the possibility of insider arbitrage to market over reaction } \\
\text { and possible links to accounting. It is very much a paper about information flows and determining how markets work. We contribute } \\
\text { by undertaking comparative winner/loser research, in two countries with different legislation, business culture, and } \\
\text { institutional/family/individual stock ownership. Such research is very limited in cultures different from the Anglo/Saxon developed } \\
\text { market world and our research will offer a benchmark to undertake further international comparative studies. The different business } \\
\text { cultures of Asia and Eastern Europe offer substantial research extensions. }\end{array}$ \\
\hline (K) Other Considerations & $\begin{array}{l}\text { The major problem is to decide the event sequence of when an insider trades and on what is the driving information factor? For } \\
\text { example does an insider contrarian trade on the string of earning increases/decreases or the string of CAR increases/decreases or } \\
\text { simply react to market over-reaction? Moreover control factors will also need to be carefully considered and they will differ between } \\
\text { the US and HK. }\end{array}$ \\
\hline
\end{tabular}




\section{Appendix B: Phase II Registered Study Plan Guidelines}

(1) Registered Pitch (Phase I) - to be included as an important reference point

Please note that, to facilitate the ongoing positive development of ideas and plans for your study, some fine-tuning of the Stage 1 registered pitch is still allowable \& appropriate in Stage II of the registered study plan. The overall guiding principles for such pitch modifications are: (a) that the core thrust of your original pitch is NOT compromised; (b) the amendments to your pitch are deemed relatively minor; (c) the amendments help achieve a coherent and "seamless" transition from pitch to full study plan (covered by headings (2) and (3) below).

(2) Hypotheses

\section{Comment}

1. Can the (numbered) hypotheses be described in terms of relationships between the conceptual or theoretical variables?

This is asking if the hypotheses are developed or consistent with theory.

Have the major pieces of literature been reviewed? (For the reviewer, is any substantive literature missing?)

2. Can the (numbered) hypotheses be between the empirical variables?

This is asking if the hypotheses can be tested.

Think about the internal and construct validities (the Libby diagram below might assist your thinking about these).

A figure or table may help describe more complex relationships.

3. Are there:

Competing "stories", contrary positions? Alternative explanations?

Interactions?

How will these be handled in the method and analysis stages?

(3) Method and Plan

Empirical Model

1. What is the model?

This can be easier if the (base) model is standard in the literature - in which case a clear reference to a specific paper and relevant equations (with page reference(s)), might help make this efficiently concise in the study registration stage.

2. What are the variables?

Be as specific as possible.

Independent

Dependent

Controls

3. In the main ("signature") analysis, how will the variables be

Note that simply referring to a study might be too restrictive as variations will end up in the postMeasured? registration analysis.

Transformed? 
Scaled?

Is multicollinearity likely?

Reviewers ought to consider alternative ways of

4. Is there a clear plan for robustness measuring variables and what sensitivity analysis checking? What are might be appropriate.

reasonable/meaningful alternative ways of modelling and estimating the relationships, measuring the variables, time periods and any measures needed for sensitivity analysis?

5. What additional analysis might be necessary to rule out alternative explanations?

Data \& Sampling strategy

6. What data will be used?

There should be sufficient data such that the project is replicable. What is the likely sample size - both overall, and in terms of any likely sub-analysis?

7. What is the sampling plan?

What are the exclusion criteria?

How will outliers be handled?

Miscellaneous

Reviewers ought to consider alternative data sources

If the planned exclusion criteria are not robust, then any additional criteria must be brought to the attention of the reviewer. The additional criteria will need to be tagged (footnoted) in the paper.

1. Causality - the extent to which causality is at issue in your proposed study, what is your identification strategy?

2. Are the statistical methods appropriate?

3. Do the proposed statistical tests relate back If the linkage of testing and hypotheses is to a hypothesis? indirect, why is the proposed element of analysis needed?

4. Economic significance

Assuming that the study achieves statistical significance, how will economic significance be assessed?

Overall

Is there any possible contingency or assumption that needs to be discussed with the reviewer? 
Libby Boxes

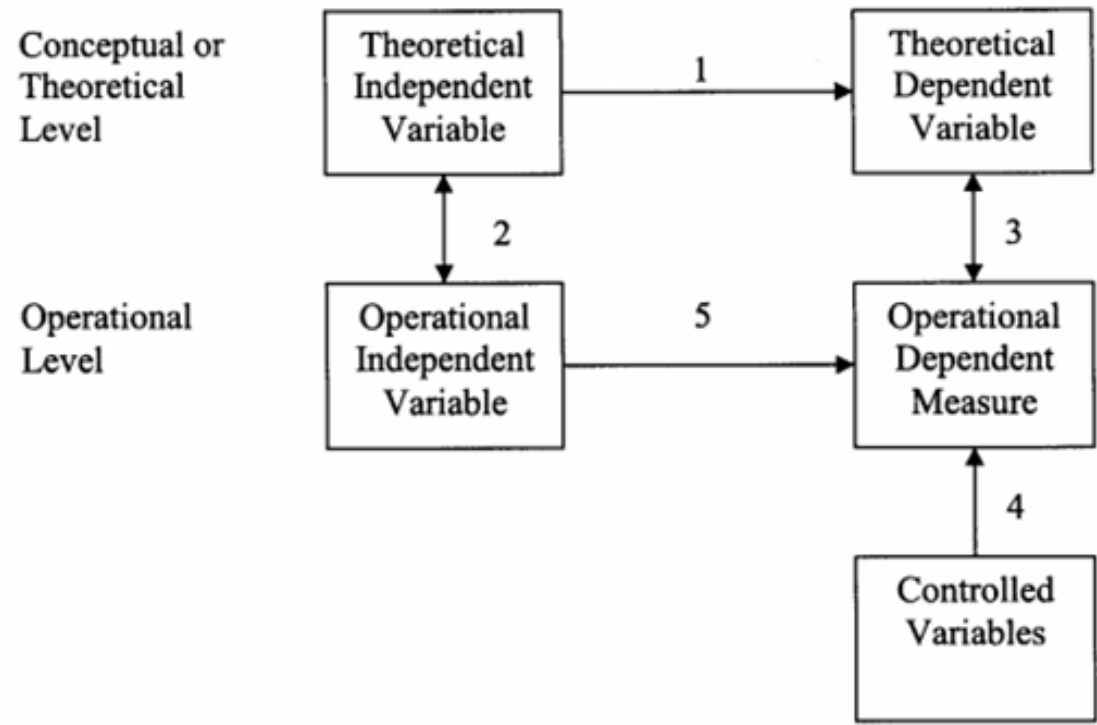

Validity links:

1. Internal validity

2. and 3. Construct validity

5. Statistical validity 